Review Article

\title{
Sprinting in road cycling - literature review
}

\author{
Paul Merkes ${ }^{1}$, Paolo Mensapà ${ }^{1}$, Chris Abbiss ${ }^{1}$. \\ ${ }^{1}$ Centre for Exercise and Sports Science Research, School of Medical and Health Sciences, Edith Cowan \\ University, Joondalup, WA, Australia
}

* Correspondence: Paul Merkes. p.merkes@ecu.edu.au

Received: 28 September 2020; Accepted: 2 October 2020; Published: 2 October 2020;

\begin{abstract}
A road cycling sprint can be described as the acceleration which occurs toward the end of competitions in order to reach the finish line in front of other competitors. The ability to sprint in road cycling is important since most races are decided in either a head-to-head, small group, or mass sprint finish. Cycling velocity during sprints is important. Factors influencing cycling velocity include the cyclist's physiology, biomechanics and application of force, resistive forces caused by the environment, and the interaction between cyclists. To perform well in sprints, road cyclists are required to have a very well developed aerobic function but also extremely well established anaerobic capacity. Cyclists can produce higher power outputs while adopting a standing position when compared with a seated position, with professional male and female sprinters producing approximately 14.2 and $10.0 \mathrm{~W} \cdot \mathrm{kg}-1$ during road sprints which last 14 and $22 \mathrm{~s}$, respectively. Additionally, lowering the torso and head during the standing sprint position results in an aerodynamic improvement of around 25\%. Before starting the sprint, road cycling sprinters can save energy by drafting behind other cyclists. However, being close to the front of the peloton during the last part of the race, together with several supporting teammates, is of high importance for cycling performance outcomes. Road cycling sprinting performance could be improved via increasing power output, reducing aerodynamic drag, and smart positioning in the peloton.
\end{abstract}

Keywords: aerodynamics, power output, performance, cyclist specialisation, sprint 


\section{Introduction}

The Union Cycliste Internationale (UCI) hosts twenty World Championships every year, which are separated over seven disciplines (Bicycle Motocross (BMX), cyclo-cross, mountain bike, road, track, trials, and indoor cycling). The majority of these races include some form of sprinting, up to one minute (BMX cross and time trial; mountain bike four cross; and track time trial, keirin, sprint, and team sprint); a possible sprint finish at the end of a mass start event (cyclo-cross, mountain bike cross country and cross country eliminator, road race, and track scratch); or repeated sprints for intermediate sprint lines and the finish line (track points race and madison). As such, sprinting is a major determinant of performance in a range of UCI World Championship events. Given differences in the physical demands and rules between various cycling disciplines, the physiological and performance characteristics of specialised 'sprinters' can be vastly different. Indeed, sprinting is a specialisation common to both track and road cycling and despite similarities in the terminology used to describe these events, the task demands are extremely different and as such their physiological and performance characteristics are different. Despite this, a commonality between sprinters from varying disciplines is their ability to produce high power outputs for short periods, when compared with other cyclists competing in the same setting. Elite track sprinters can generally produce the highest peak power output across all the disciplines of track cycling. Similarly, road sprinters are generally able to produce the highest peak power outputs within the road cycling peloton, making comparisons between these two specialists interesting. Due to neural (i.e. higher peak cadences) and anthropometric characteristics (i.e. greater lower limb muscle mass) differences, professional track sprinters can typically produce considerably higher absolute peak power outputs than road sprinters (peak power: $\geq 1600 \mathrm{~W}$ and $\geq 1100 \mathrm{~W}$, respectively) (Dorel et al., 2005; Gardner, Martin, Martin, Barras, \& Jenkins, 2007; Menaspà, Quod, Martin, Peiffer, \& Abbiss, 2015; Menaspà, Quod, Martin, Victor, \& Abbiss, 2013). Despite limited published data, it seems that when accounting for body mass the power output is more comparable between road and track sprinters (Menaspà, Martin, et al., 2013). To date, there has been considerably more research examining track sprint cycling (Capelli et al., 1998; Dorel et al., 2005; Gardner et al., 2009; Gardner et al., 2007; McLean \& Parker, 1989; Schumacher, Mueller, \& Keul, 2001), when compared with road sprinting. This is somewhat surprising since sprints are very common in road cycling, with over half of the mass-start stages during the three grand tours (i.e. Giro d'Italia, Tour de France, and Vuelta a España), as well as several of the recent World Championships decided in either a head-to-head, small group, or mass sprint finish. While there are multiple literature reviews (Atkinson, Davison, Jeukendrup, \& Passfield, 2003; Crouch, Burton, LaBry, \& Blair, 2017; Faria, Parker, \& Faria, 2005a, 2005b; Lucia, Hoyos, \& Chicharro, 2001; Rønnestad \& Mujika, 2014; Santalla, Earnest, Marroyo, \& Lucia, 2012) available examining cycling performance more generally, no study has combined and summarised the growing body of knowledge specifically examining the factors influencing road cycling sprint performance. Therefore, the purpose of this review was to: i) define and describe sprinting in road cycling, ii) provide an overview of the physiological capabilities required to perform at a professional level, iii) describe the interaction between the cyclist and bicycle during a road sprint, and iv) outline the effect of other cyclists on road sprint cycling performance (the interaction between cyclists).

\section{Sprinting in Road Cycling}

Professional road cycling is an extremely demanding sport. To participate at the highest level, male road cyclists ride approximately 22,000 to $35,000 \mathrm{~km}$ in training and competitions per year (Metcalfe et al., 2017; Nimmerichter, Eston, Bachl, \& Williams, 2011; Pinot \& Grappe, 2015). The mean weekly training duration for road cyclists is approximately 16 to $25 \mathrm{~h}$ (Nimmerichter et al., 2011; Pinot \& Grappe, 2015), which is close to twice the amount of training hours per week when compared with marathon runners 
(Stellingwerff, 2012). Professional male and female cyclists have been reported to participate in at least 30 and up to 95 races each year (Pro-Cycling-Stats).

Cycling velocity is incredibly important in road cycling competitions, since even during multi-stage events, the cyclist who finishes the race in the shortest time wins. Cycling velocity is influenced by a range of factors including the cyclist's physical capacities (De Pauw et al., 2013; Fintelman, Sterling, Hemida, \& Li, 2014; Nimmerichter et al., 2011; Novak \& Dascombe, 2014; Pinot \& Grappe, 2015); opposing resistances (i.e. gravity, wind, acceleration, and friction (Martin, Gardner, Barras, \& Martin, 2006b)); the interaction between cyclist and bicycle (Crouch et al., 2017; Fintelman et al., 2014; Hansen \& Waldeland, 2008); and the interaction between cyclists (Blocken et al., 2018; Menaspà, Abbiss, \& Martin, 2013). Sprinting is the fastest activity on a bicycle (with the exclusion of some descending) in which male (Menaspà, Quod, et al., 2015) and female (Peiffer, Abbiss, Haakonssen, \& Menaspà, $2018 b$ ) cyclists reach peak velocities near or in excess of $70 \mathrm{~km} \cdot \mathrm{h}-1$. A road cycling sprint has been defined as 'the acceleration which occurs toward the end of competitions in order to reach the finish line in front of other competitors' (Menaspà, Quod, et al., 2015). Typically, the road cycling sprint takes place after hours of endurance cycling and can be compared with the final acceleration in marathon running. Towards the end of the race power output gradually increases and is followed by a final dash to the finish line (Menaspà, Quod, et al., 2015). The duration of the final sprint ranges between 9 and $17 \mathrm{~s}$ for both male professional and under 23 (U23) cyclists (Martin, Davidson, \& Pardyjak, 2007; Menaspà, Abbiss, et al., 2013; Menaspà, Quod, et al., 2015; Menaspà, Quod, et al., 2013), and between 10 and $33 \mathrm{~s}$ in professional female cyclists (Peiffer et al., 2018b).

In addition, within some road cycling events, cyclists also sprint for intermediate sprints. In fact, during multi-stage races, 'intermediate' and 'King of the Mountain' sprint lines are often placed along the course. At the intermediate sprint lines, cyclists can earn bonus seconds for the general classification and/or points for a dedicated points jersey (also known as sprint jersey). The King of the Mountain sprint lines are places on top of a hill or mountain. At these lines, cyclists can earn points for the King of the Mountain jersey. There is currently no research available examining these intermediate sprints. Further research is needed to better understand the factors important to success in intermediate sprints and implications of such sprints to overall outcomes on general, sprint, and King of the Mountain classifications. Regardless, the existence of these sprints further highlights the importance of understanding sprinting characteristics within road cycling.

\section{The Cyclist's Physiology and Capabilities}

Road cyclists can fulfil several different roles throughout a race based on tactical decisions, and the athlete's physiological and performance characteristics. One characteristic that discriminates road cycling sprinters from other specialists, is their capacity to produce extremely high power outputs over relatively short durations (Pinot \& Grappe, 2011; Sallet, Mathieu, Fenech, \& Baverel, 2006). However, road cycling sprinters are also required to reach each intermittent or final sprint at the same time as other competitors to compete in the final dash to the line. As a result, road sprint cyclists are not only required to be able to produce high sprint power outputs but also be able to resist fatigue prior to and during the sprint. The athletic demands of road cycling sprints, road sprint cycling specialisation, and how to measure sprint performance is discussed below.

\section{Athletic Demands of Road Cycling Sprinting}

The energetic demands during road cycling races are predominantly placed on the aerobic metabolism (Lucia et al., 2001; Mujika \& Padilla, 2001) and road cycling is therefore often described as an aerobic event (De Pauw et al., 2013; Lucia et al., 2001; Mujika \& Padilla, 2001). However, road cycling can be seen as an intermittent sport in which several short and high intensity efforts are repeated (Abbiss, Straker, Quod, Martin, \& Laursen, 2010), during which a contribution of 
anaerobic metabolism is required (Faria et al., 2005b; Fernandez-Garcia, Perez-Landaluce, Rodriguez-Alonso, \& Terrados, 2000; Olds, 2001). For example, short high intensity efforts are required when establishing a breakaway (i.e. riding away from a group of cyclists) (Abbiss, Menaspà, Villerius, \& Martin, 2013), climbing a steep hill, or during intermediate and final road cycling sprints (Martin et al., 2007; Menaspà, Abbiss, et al., 2013; Menaspà, Quod, et al., 2015; Menaspà, Quod, et al., 2013). Several studies (Abbiss, Burnett, et al., 2010; Del Coso, Hamouti, Aguado-Jimenez, \& Mora-Rodriguez, 2009; Etxebarria, Ingham, Ferguson, Bentley, \& Pyne, 2019; Menaspà, Martin, Victor, \& Abbiss, 2015; Schabort, Hawley, Hopkins, Mujika, \& Noakes, 1998; Sharma, Elliott, \& Bentley, 2015) have attempted to replicate the stochastic nature of power output observed during road cycling races (Abbiss, Straker, et al., 2010). The participants in these studies (Abbiss, Burnett, et al., 2010; Del Coso et al., 2009; Etxebarria et al., 2019; Menaspà, Martin, et al., 2015; Schabort et al., 1998) were not classified as sprinters. As such, it is possible that sprint performance of specialised road sprinters (who typically have lower aerobic characteristics when compared with other road cycling specialisations (Menaspà et al., 2012; Sallet et al., 2006)) could potentially be affected by the high-intensity variability of road races. Additionally, some of these studies (Abbiss, Burnett, et al., 2010; Del Coso et al., 2009; Etxebarria et al., 2019; Schabort et al., 1998; Sharma et al., 2015) combined periods of high intensity (e.g. 1 or $4 \mathrm{~min}$ ) with submaximal cycling but did not account for the high demands of the long lead-up phase of a road cycling race (Menaspà, Quod, et al., 2015; Menaspà, Quod, et al., 2013). Indeed, professional road cycling sprints occur following a long lead-up period during which cyclists are typically riding at or above mean maximal power of $1 \mathrm{~h}$ for extended periods (Menaspà, Quod, et al., 2013). Additionally, cyclists will most likely be riding close to or above their critical power $(\mathrm{CP})$ and $\mathrm{VO} 2 \mathrm{max}$ in the final stages before the final acceleration to the finish line. $\mathrm{CP}$ is the highest power output at which oxygen consumption and blood lactate are stable (Poole, Ward, Gardner, \& Whipp, 1988). When riding above
$\mathrm{CP}$, cyclists are most critically limited by their finite amount of energy coming from the anaerobic metabolism (Fukuba et al., 2003; Fukuba \& Whipp, 1999; Palmer, Dennis, Noakes, \& Hawley, 1996). It can be concluded that road cycling sprint performance can be improved by either improving anaerobic capacity or the maximal rate of aerobic metabolism (VO2max).

Much of the available research in sprinting has examined performance in a non-fatigued state (Menaspà et al., 2012; Munro, Stannard, Fink, \& Foskett, 2017; Sallet et al., 2006; Tofari, Cormack, Ebert, Gardner, \& Kemp, 2017). However, there is currently a paucity of research that has specifically examined the metabolic requirements of road sprinting, especially following 1-7 $\mathrm{h}$ of cycling. Adenosine triphosphate resynthesises during non-fatigued sprints is heavily reliant on the anaerobic metabolism in particular, phosphocreatine (phosphagen system) and the degradation of muscle glycogen to lactic acid (anaerobic glycolysis) (Bangsbo, Krustrup, Gonzalez-Alonso, \& Saltin, 2001; Gaitanos, Williams, Boobis, \& Brooks, 1993; Gastin, 2001; Jones et al., 1985; Parolin et al., 1999). It is important to note that a road cycling sprint occurs after hours, and sometimes after multiple days of racing including a long lead-up phase. As a result, road sprint cyclists are somewhat unique and have to be able to rapidly produce high power outputs in multiple states of fatigue. However, it is also important to consider that pacing within the sprint is not dictated solely by metabolic pathways. Indeed, any energy carried over the finish line is essentially wasted energy. Therefore, using this energy to accelerate rapidly is important in road sprint cycling. The rapid increase in power output is often caused by cyclists starting their sprints by standing out of their saddle and getting out of the slipstream of another cyclist in front (Menaspà, Abbiss, et al., 2013) and followed by a quick decline in power output during the rest of the sprint (Martin \& Brown, 2009; O'Bryan, Brown, Billaut, \& Rouffet, 2014). Current literature has been important in identifying power output during a sprint at the end of a race and in a non-fatigued state. There is currently limited literature 
examining the behaviour of opponents which might affect pacing strategies and performance (Konings, Parkinson, Zijdewind, \& Hettinga, 2018; Konings, Schoenmakers, Walker, \& Hettinga, 2016). Additionally, no studies are available describing the difference in road cycling sprint power output before and at the end of a road cycling race, most likely due to its practical limitations.

\section{Cycling Specialists and Road Cycling Sprinters}

Despite competing in the same races, a significant difference in anthropometric, physiological, and performance characteristics exists between various road cycling specialists (Impellizzeri et al., 2008; Lucia, Joyos, \& Chicharro, 2000; Menaspà et al., 2012; Padilla, Mujika, Cuesta, \& Goiriena, 1999; Pinot \& Grappe, 2011; Sallet et al., 2006). To date, much of the literature has described and compared the physiological characteristics of uphill, flat terrain, all terrain, and time trial specialists (Impellizzeri et al., 2008; Lucia et al., 2000; Padilla et al., 1999; Pinot \& Grappe, 2011). Interestingly, only one study has compared the anthropometric and physiological characteristics (Sallet et al., 2006), and two studies have compared the performance characteristics (Pinot \& Grappe, 2011; Sallet et al., 2006) of adult road cycling sprinters with other specialists. In one of the studies (Sallet et al., 2006) it has been shown that male road cycling sprinters have similar height $(175.6 \pm 2.1 \mathrm{~cm})$, body mass $(67.3 \pm 2.5$ $\mathrm{kg})$, body fat percentage $(8.2 \pm 2.3 \%), \mathrm{VO} 2 \mathrm{max}$ $(71.8 \pm 4.7 \mathrm{~mL} \cdot \mathrm{kg}-1 \mathrm{~min}-1), \mathrm{MAP}(428.2 \pm 32.5$ $\mathrm{W}$ and $6.3 \pm 0.3 \mathrm{~W} \mathrm{~kg}-1)$, and gross mechanical efficiency $(25.4 \pm 1.4 \%)$, when compared with other specialists. These results must be interpreted with caution since this was a cross-sectional study design and only 4 of the 71 participants were classified as road cycling sprinters. In addition, the road cycling sprinters $(20.2 \pm 2.6 \mathrm{y} ; \mathrm{n}=4)$ were significantly younger than the uphill $(23.6 \pm 3.6 \mathrm{y} ; \mathrm{n}=24)$, flat terrain $(23.5 \pm 3.9 \mathrm{y} ; \mathrm{n}=32)$, and all terrain cyclists $(27.7 \pm 4.8 ; \mathrm{n}=11)$. Additionally, 45 participants were classified as professional cyclists and 26 as elite cyclists; however, it is unclear how many of the 4 road cycling sprinters were professional or elite cyclists. These limitations could explain why there were no differences found for the anthropometric, physiological, and performance characteristics. A different study (Menaspà et al., 2012), however, showed that under 19 (U19) male road cycling sprinters were heavier, taller, and had a higher body mass index than uphill cyclists. Additionally, U19 road cycling sprinters had a lower $\mathrm{VO} 2 \mathrm{max}$ and MAP relative to body mass (61.9 $\pm 4.1 \mathrm{~mL} \cdot \mathrm{kg}-1 \mathrm{~min}-1$ and $5.5 \pm 0.4 \mathrm{~W} \cdot \mathrm{kg}-1)$ when compared with uphill cyclists $(67.5 \pm 5.0$ $\mathrm{mL}$ kg- 1 min-1 and $6.2 \pm 0.6 \mathrm{~W}$ kg-1) which could be partly explained by the higher body mass among sprinters. The greater body mass typically observed in road cycling sprinters, when compared with other specialisations, is likely to be the result of the large muscle mass required to produce the high sprint cycling power outputs. Since road cycling sprinters are often competitive during relatively flat races, a gain in power output as a result of greater muscle mass typically outweighs the negative effects caused by relatively greater body mass. Comparatively, a lower body mass is incredibly important in climbing given the high energy cost associated with overcoming gravity (Martin, Milliken, Cobb, McFadden, \& Coggan, 1998; Mujika \& Padilla, 2001). Competitive female cyclists with greater lower-body lean mass produced greater mean maximal power output (Haakonssen, Martin, Martin, Burke, \& Jenkins, 2013). For example, an increase of 1 $\mathrm{kg}$ lower-body lean mass resulted in an increase of approximately 9 and $4 \%$ in $1 \mathrm{~s}$ and 10 min mean maximal power output, respectively (Haakonssen et al., 2013). Additionally, $1 \mathrm{~kg}$ of muscle mass was associated with an increase of $35 \mathrm{~W}$ during a $30 \mathrm{~s}$ sprint (Haakonssen et al., 2013). It should be noted that we are unaware of research specifically modelling the balance between muscle mass, body mass, and cycling performance across a range of course geographies and within a variety of cycling specialisations (e.g. uphill specialists and sprinters), which may be an interesting area for future research.

Through examining the power outputs observed across a range of studies in U19/U23/elite/professional male road cycling sprinters (Table 1) it can be seen that 
for the average sprint duration of approximately 14 s (Martin et al., 2007; Menaspà, Abbiss, et al., 2013; Menaspà, Quod, et al., 2015; Menaspà, Quod, et al., 2013) elite/professional male cyclist can produce approximately $14.2 \mathrm{~W} \cdot \mathrm{kg}-1$ (Figure 1 ). Both case studies (Martin et al., 2007; Menaspà, Quod, et al., 2013) deviate from the trendline, possible due to the small sample size or the participant in these studies was simply a better (Menaspà, Quod, et al., 2013) or worse (Martin et al., 2007) sprinter compared with the sprinters in the other studies. Less studies are available about sprint performance in female road cyclists (Table 2). From the available research, it can be seen that professional female road cyclists can produce a power output of approximately $10.0 \mathrm{~W} \cdot \mathrm{kg}-1$ for an average sprint duration of $22 \mathrm{~s}$ (Peiffer et al., 2018b) (Figure 2).

The cadence observed in road sprint cycling is vastly lower than in track cycling. Indeed, the average cadence during male and female road cycling sprints has been shown to be approximately 110 (Menaspà, Martin, et al., 2013; Menaspà, Quod, et al., 2015) and 103 rpm (Peiffer, Abbiss, Haakonssen, \& Menaspà, 2018a) with a peak cadence of approximately 114 (Menaspà, Quod, et al., 2015) and $110 \mathrm{rpm}$ (Peiffer et al., 2018a), respectively. Peak and mean cadence in male track cyclists has been shown to be approximately 155 (Craig \& Norton, 2001; Gardner, Martin, Barras, Jenkins, \& Hahn, 2005) and 135 (Craig \& Norton, 2001; Menaspà, Martin, et al., 2013), respectively. This difference in cadence has significant implications for the neural constraints that influence sprint performance in these two disciplines and therefore the training strategies that are likely to result in optimal adaptation and performance. Cadence has an effect on kinetics and kinematics during cycling. For example, increasing cadence has been shown to decrease ankle and knee joint range of motion (Bini, Rossato, et al., 2010; Bini, Tamborindeguy, \& Mota, 2010; McDaniel, Behjani, Elmer, Brown, \& Martin, 2014; Rauen, Angeloudis, \& Falconer, 2012) while hip joint range of motion increased during sprints (McDaniel et al., 2014). Such a decrease in ankle joint range of motion may be important especially at higher power outputs or when a cyclist is fatigued as it allows the stabilisation of the joint and transfer of high power output from the hip and knee to the pedal (Bini, Tamborindeguy, et al., 2010; McDaniel et al., 2014; Rauen et al., 2012). Indeed, power produced at the hip and knee is transferred to the pedal via the ankle. Conversely, studies have also shown no changes in hip and knee range of motion during submaximal efforts (Bini, Tamborindeguy, et al., 2010). The difference in results between these studies might be explained by the power contribution of each joint at low versus high power outputs. A different effect of an increased cadence on kinetics is that it leads to an increase in knee joint power contribution and a decreased hip joint power contribution during either submaximal or maximal cycling (Elmer, Barratt, Korff, \& Martin, 2011; Hoshikawa, Takahashi, Ohashi, \& Tamaki, 2007; Mornieux, Guenette, Sheel, \& Sanderson, 2007; Sanderson, Mornieux, Guenette, \& Sheel, 2008; Skovereng, Ettema, \& van Beekvelt, 2017; Strutzenberger, Wunsch, Kroell, Dastl, \& Schwameder, 2014). This interaction between hip and knee contribution acts in such a way that they compensate for one another to maintain pedal power. According to the majority of available studies ankle contribution does not change with changes in cadence (Bini, Rossato, et al., 2010; Elmer et al., 2011; Hoshikawa et al., 2007; Mornieux et al., 2007; Sanderson et al., 2008; Skovereng et al., 2017; Skovereng, Ettema, \& van Beekvelt, 2016; Strutzenberger et al., 2014), except for one study that reported an increased ankle contribution when changing a cadence from 40 to $70 \mathrm{rpm}$ (from $\sim 3.5$ to $\sim 4 \%$ of overall power contribution) (Bini, Tamborindeguy, et al., 2010). It is unclear why an increase in ankle contribution was observed in this particular study but it could be due to the low cycling level of the participants (healthy males without experience in cycling competition) and therefore poor pedalling technique (Bini, Tamborindeguy, et al., 2010). It can be concluded that an increased cadence leads to a shift in total power contribution of the hip and knee with the knee providing a greater contribution to the overall power output. 
Table 1 - Power output and cadence during sprints in male road cycling (Mean \pm SD)

\begin{tabular}{|c|c|c|c|c|c|c|c|c|c|c|c|c|c|c|c|c|c|c|}
\hline Reference & Level & $\begin{array}{l}\text { Type of } \\
\text { data } \\
\text { collection }\end{array}$ & $\begin{array}{l}\mathrm{n} \\
\text { cyclis } \\
\text { ts }\end{array}$ & $\begin{array}{l}\mathrm{n} \\
\text { sprint } \\
\mathrm{s} \text { per } \\
\text { cyclis } \\
\mathrm{t} \\
\end{array}$ & $\begin{array}{l}\text { Age } \\
\text { (y) }\end{array}$ & & & $\begin{array}{l}\text { Sprin } \\
\text { (s) }\end{array}$ & ura & & $\begin{array}{l}\text { Power } \\
\left(\mathrm{W} \cdot \mathrm{kg}^{-1}\right)\end{array}$ & & & & $\begin{array}{l}\text { Caden } \\
(\mathrm{rpm})\end{array}$ & & & \\
\hline \multirow[t]{2}{*}{$\begin{array}{l}\text { Martin et al., } \\
2007\end{array}$} & $\begin{array}{l}\text { Professiona } \\
1\end{array}$ & $\begin{array}{l}\text { Final sprint } \\
\text { during a } \\
\text { race }\end{array}$ & 1 & 1 & \multirow{2}{*}{\multicolumn{3}{|c|}{-}} & \multirow{2}{*}{\multicolumn{3}{|c|}{14.0}} & Peak & \multicolumn{3}{|l|}{13.7} & \multicolumn{4}{|l|}{-} \\
\hline & & & & & & & & & & & Mean & 11.6 & & & & & & \\
\hline $\begin{array}{l}\text { Menaspà et al., } \\
2012\end{array}$ & U19 & Laboratory & 25 & 1 & 16.9 & \pm & $\begin{array}{l}0 . \\
6\end{array}$ & 5.0 & & & Mean & 16.6 & \pm & 0.6 & Peak & 157.0 & \pm & 5.0 \\
\hline \multirow{4}{*}{$\begin{array}{l}\text { Menaspà, } \\
\text { Martin, et al., } \\
2013\end{array}$} & \multirow{4}{*}{$\begin{array}{l}\text { Professiona } \\
1\end{array}$} & \multirow{4}{*}{$\begin{array}{l}\text { Maximal } \\
\text { mean } \\
\text { power } \\
\text { during } \\
\text { races }\end{array}$} & \multirow[t]{4}{*}{3} & \multirow[t]{4}{*}{-} & \multirow[t]{4}{*}{26.0} & \multirow[t]{8}{*}{ \pm} & 3. & \multicolumn{3}{|l|}{1.0} & Mean & 18.8 & \pm & 2.1 & \multirow[t]{4}{*}{ Peak } & \multirow[t]{4}{*}{109.0} & \multirow[t]{4}{*}{ \pm} & \multirow[t]{4}{*}{$6.0^{*}$} \\
\hline & & & & & & & & 10.0 & & & Mean & 16.3 & \pm & 1.8 & & & & \\
\hline & & & & & & & & 20.0 & & & Mean & 13.1 & \pm & 1.1 & & & & \\
\hline & & & & & & & & 30.0 & & & Mean & 11.7 & \pm & 0.6 & & & & \\
\hline \multirow[t]{2}{*}{$\begin{array}{l}\text { Menaspà, Quod, } \\
\text { et al., } 2013 \text { (PRO) }\end{array}$} & $\begin{array}{l}\text { Professiona } \\
1\end{array}$ & $\begin{array}{l}\text { Final sprint } \\
\text { during } \\
\text { races }\end{array}$ & 1 & 4 & 23.0 & & & 14.5 & \pm & 2.4 & Peak & 19.1 & \pm & 0.7 & \multirow{2}{*}{\multicolumn{2}{|c|}{-}} & & \\
\hline & & & & & & & & & & & Mean & 15.6 & \pm & 0.4 & & & & \\
\hline \multirow[t]{2}{*}{$\begin{array}{l}\text { Menaspà, Quod, } \\
\text { et al., } 2013 \text { (U23) }\end{array}$} & $\mathrm{U} 23$ & $\begin{array}{l}\text { Final sprint } \\
\text { during } \\
\text { races }\end{array}$ & 1 & 5 & 18.0 & & & 12.8 & \pm & 1.1 & Peak & 20.6 & \pm & 1.0 & \multirow{2}{*}{\multicolumn{2}{|c|}{ - }} & & \\
\hline & & & & & & & & & & & Mean & 17.4 & \pm & 1.1 & & & & \\
\hline \multirow[t]{2}{*}{$\begin{array}{l}\text { Menaspà, Quod, } \\
\text { et al., } 2015\end{array}$} & $\begin{array}{l}\text { Professiona } \\
1\end{array}$ & \multirow[t]{2}{*}{$\begin{array}{l}\text { Final sprint } \\
\text { during } \\
\text { races }\end{array}$} & 6 & $\sim 3$ & 27.0 & \pm & $\begin{array}{l}3 . \\
8\end{array}$ & 13.2 & \pm & 2.3 & Peak & 17.4 & \pm & 1.7 & Peak & 114.0 & \pm & 5.0 \\
\hline & & & & & & & & & & & Mean & 14.2 & \pm & 1.1 & Mean & 110.0 & \pm & 5.0 \\
\hline \multirow{3}{*}{$\begin{array}{l}\text { Pinot \& Grappe, } \\
2011\end{array}$} & \multirow[t]{3}{*}{ - } & \multirow{3}{*}{$\begin{array}{l}\text { Maximal } \\
\text { mean } \\
\text { power } \\
\text { during } \\
\text { races and } \\
\text { training }\end{array}$} & \multirow[t]{3}{*}{5} & \multirow[t]{3}{*}{$\sim 250$} & \multirow[t]{3}{*}{-} & & & \multicolumn{3}{|l|}{1.0} & Mean & 20.2 & & & \multirow{3}{*}{\multicolumn{2}{|c|}{-}} & & \\
\hline & & & & & & & & 5.0 & & & Mean & $\sim 18.8$ & & & & & & \\
\hline & & & & & & & & 30.0 & & & Mean & $\sim 11.9$ & & & & & & \\
\hline Sallet et al., 2006 & - & Laboratory & 4 & 1 & 20.2 & \pm & $\begin{array}{l}2 . \\
6\end{array}$ & 30.0 & & & Peak & 19.0 & \pm & 1.1 & Peak & 216.0 & \pm & 8.8 \\
\hline
\end{tabular}


Table 2 - Power output and cadence during sprints in female road cycling (Mean \pm SD)

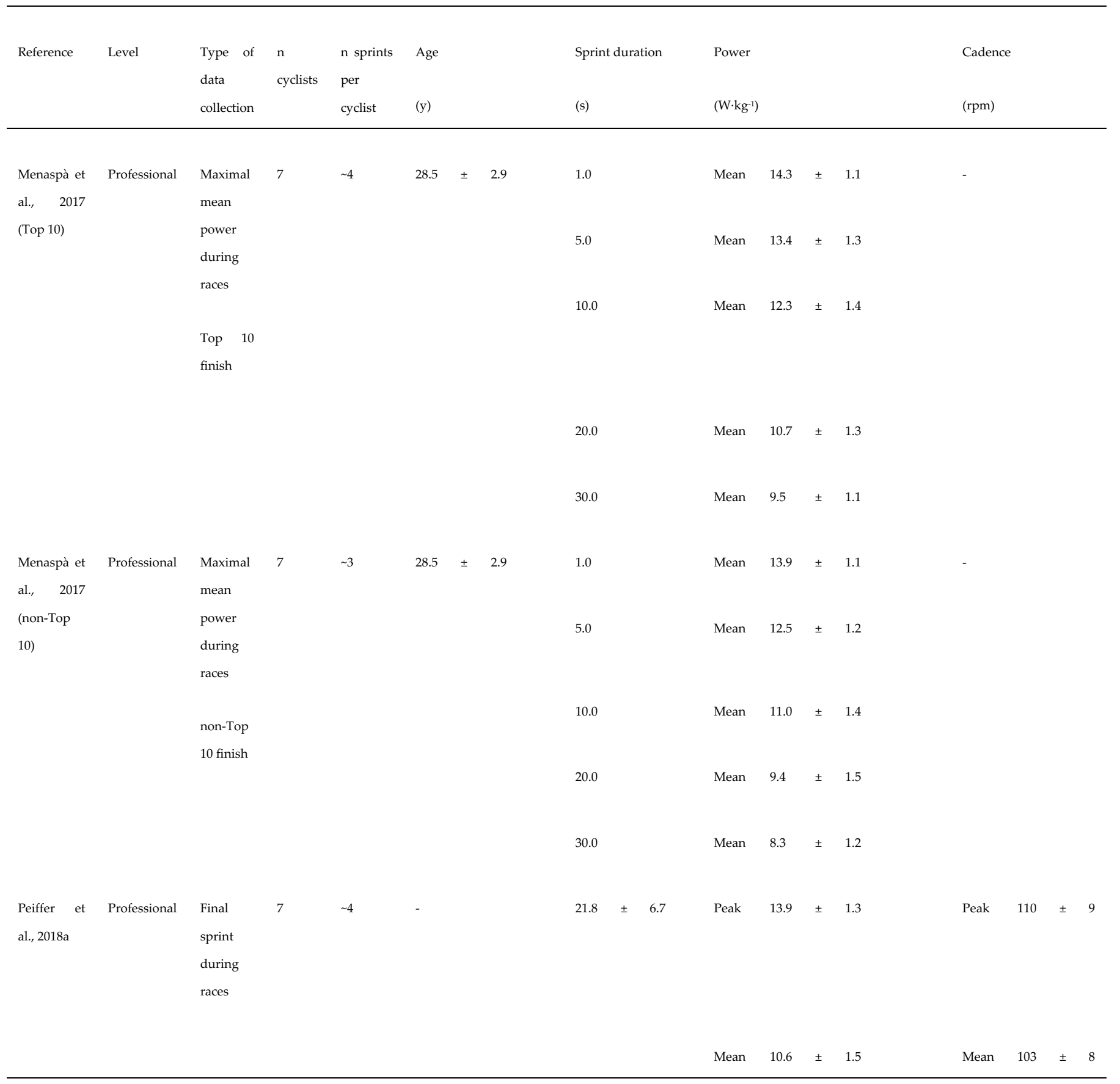

Abbreviations: $\mathrm{SD}=$ standard deviation; $\mathrm{n}=$ number 


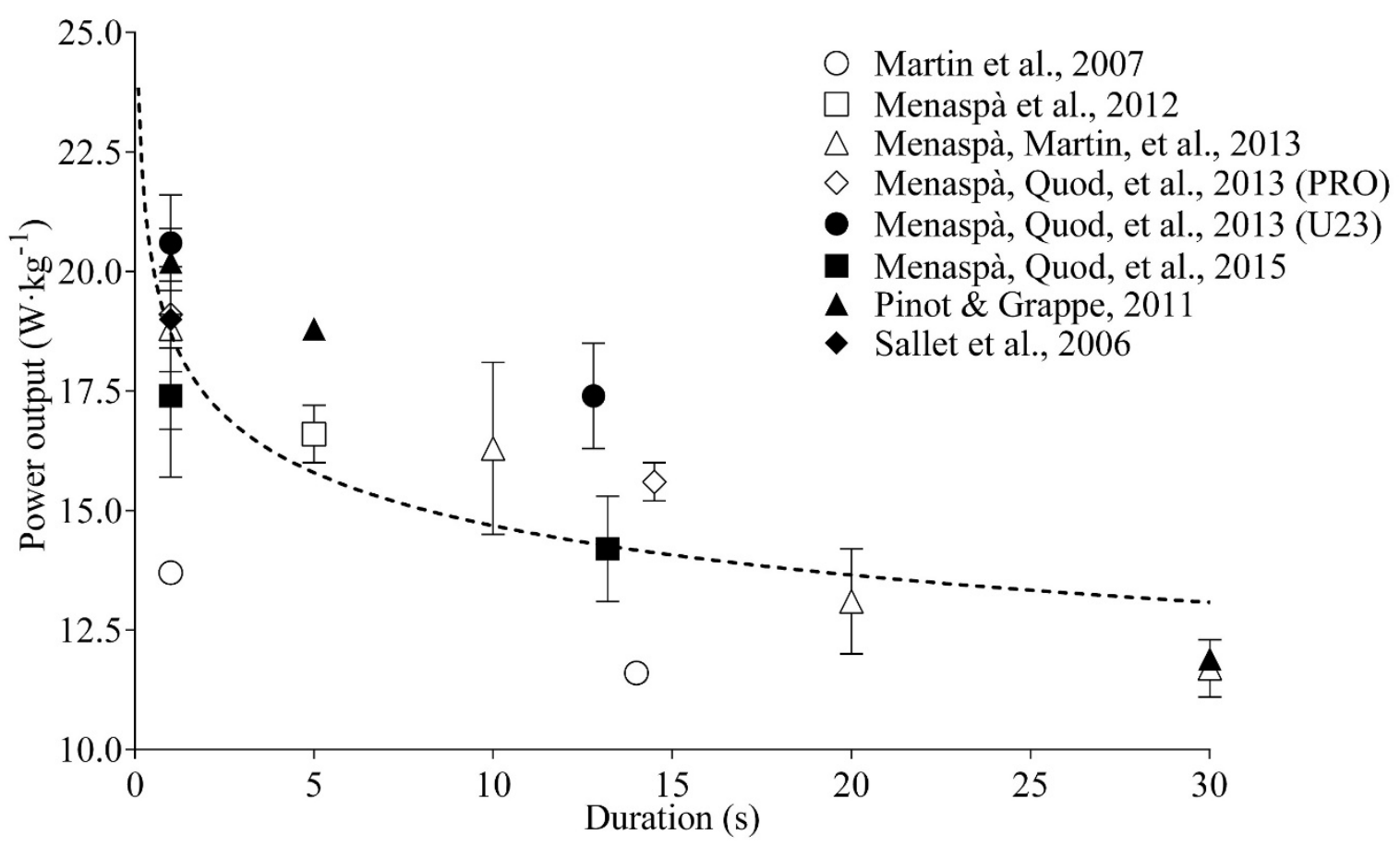

Figure 2 - Power output and sprint duration in male road cyclists

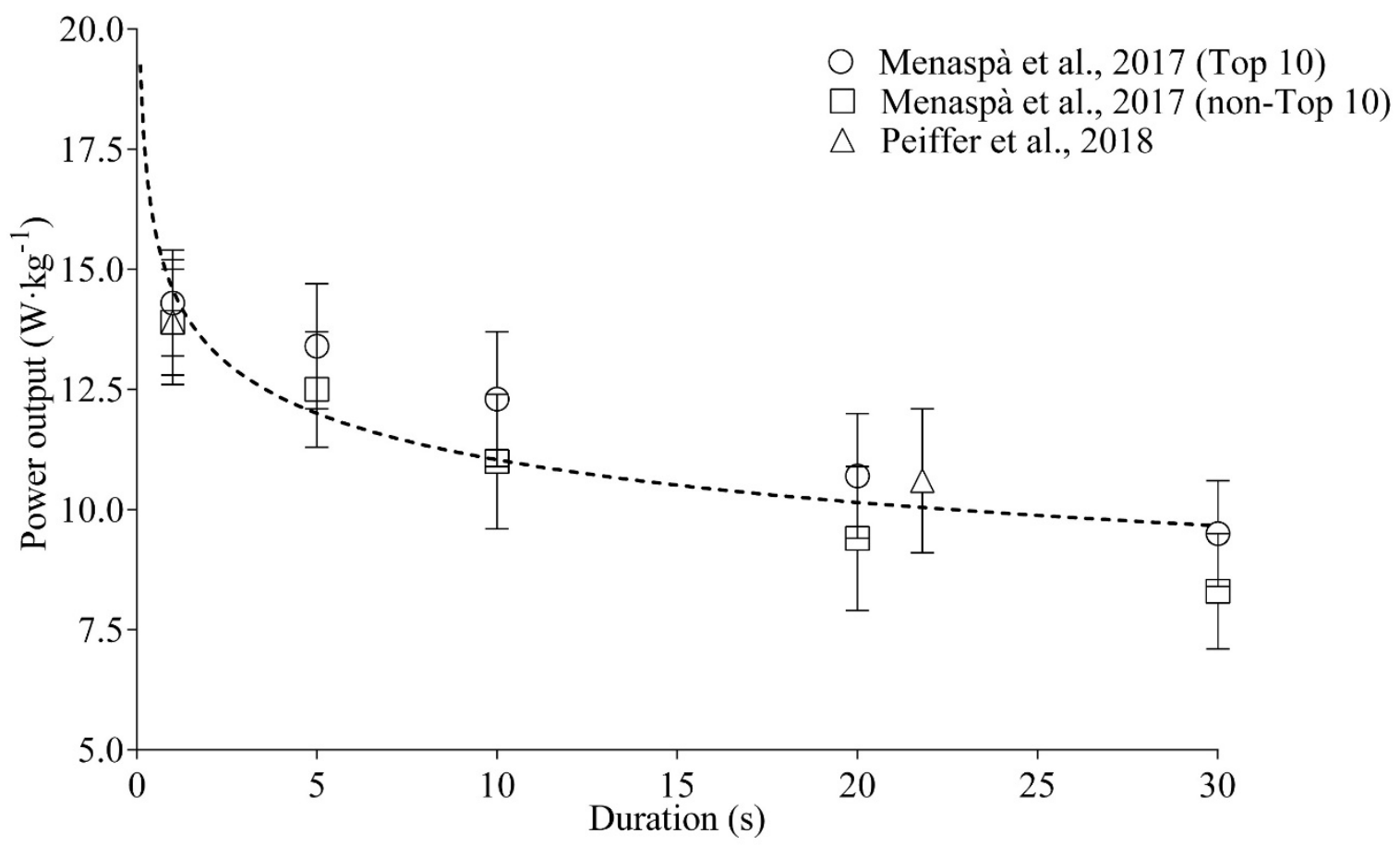

Figure 1 - Power output and sprint duration in female road cyclists 


\section{Measuring Sprint Power Output in Cycling}

To date, studies have examined the power output during the sprint in a laboratory setting (Barratt, Korff, Elmer, \& Martin, 2011; Del Vecchio et al., 2019; Harnish, King, \& Swensen, 2007; McLester, Green, \& Chouinard, 2004; Moura, Luis Moro, Rossato, de Lucas, \& Diefenthaeler, 2017; Mujika, Rønnestad, \& Martin, 2016; Padulo, Laffaye, Bertucci, Chaouachi, \& Viggiano, 2014; Reiser, Maines, Eisenmann, \& Wilkinson, 2002) and during professional road cycling races (Martin et al., 2007; Menaspà, Martin, et al., 2013; Menaspà, Quod, et al., 2015; Menaspà, Quod, et al., 2013). An important consideration when comparing laboratory and field-based cycling is that laboratorybased ergometers often have limited lateral movement (lateral sway) (Bertucci, Taiar, \& Grappe, 2005). This is especially important in sprinting because lateral sway might lead to a higher power output as a result of a higher global upper limb activity when compared with no use of lateral sway (Duc, Bertucci, Pernin, \& Grappe, 2008). However, it is worth noting that it is often difficult to obtain accurate and reliable data on muscle activity (Duc et al., 2008; Li \& Caldwell, 1998) and other factors important to sprint cycling (e.g. torque development (Watsford, Ditroilo, Fernandez-Pena, D'Amen, \& Lucertini, 2010) and optimal cadence (Martin et al., 2007)) during field-based testing. Additionally, the advantage of testing in a laboratory is that environmental conditions (e.g. temperature and wind) can be kept consistent, and allow accurate assessment of a range of factors and their effect on cycling performance including a training intervention (Del Vecchio et al., 2019; Mujika et al., 2016), bicycle setup (Barratt et al., 2011; Moura et al., 2017), or body position (Harnish et al., 2007; McLester et al., 2004; Merkes, Menaspà, \& Abbiss, 2020; Padulo et al., 2014; Reiser et al., 2002). To date, it is unclear if there are any differences in power output between sprinting in the laboratory and on the road. It has been reported that track sprinters can produce similar torque and power-pedalling rate relationships in laboratory and track-based tests (Gardner et al., 2007). Additionally, peak power output, maximal force, and time to obtain peak power output were higher $(\sim 1,69$, and $13 \%$, respectively) during a $55 \mathrm{~m}$ sprint from a standing start in a gymnasium when compared with a laboratory test (Bertucci et al., 2005). Future research could investigate the difference in the sprint performance of cyclists when sprinting on the road compared with the laboratory.

The analyses of field-based road cycling performance have, to date, typically focussed on the explosive power output throughout the dash towards the finish line (Martin et al., 2007; Menaspà, Martin, et al., 2013; Menaspà, Quod, et al., 2015; Menaspà, Quod, et al., 2013) and the lead-up phase (Menaspà, Quod, et al., 2015; Menaspà, Quod, et al., 2013). These studies have predominantly focused on the duration, and peak and mean power output achieved during the lead-up phase and the dash towards the finish line. To date, no detailed analysis exists including the effect of geography and stage profile on sprint performance; the rate of development of power output during the sprint; or the metabolic requirements and fatigue development during both lead-up phase and sprint.

\section{Interaction between Cyclist and Bicycle}

Cycling is a complex multi-joint movement, involving several important considerations which influence the delivery of force from the cyclist to the bicycle and from the bicycle to the road. This is critically important in road sprints given the maximal demands placed upon the cyclist, whereby effective maximal force transfer plays a major role in sprinting due to the maximal nature of the activity. Furthermore, road sprinting is often performed in a range of different body positions (e.g. seated and standing), which influences muscle activation and force production, the number of contact points between the bicycle and the cyclist, and the aerodynamic drag. As a result, direct comparison of cycling biomechanics, performance, and limits to performance during seating and sprint cycling is flawed. Similarly, the majority of research examining cycling while standing has focussed on uphill 
cycling and direct comparison with sprint road cycling is problematic.

\section{Cyclist's Body Position during Road Cycling Sprinting}

During prolonged road cycling, cyclists adopt a range of different body positions (e.g. seated or standing), but generally the majority of the time is spent cycling in a seated position (Arkesteijn, Jobson, Hopker, \& Passfield, 2016; Bouillod \& Grappe, 2018; Bouillod et al., 2018; Hansen \& Waldeland, 2008; Millet, Tronche, Fuster, \& Candau, 2002). To date, the majority of the literature available on this topic has examined the influence of body position on performance, fatigue, and movement economy during cycling on the flat and uphill. In a standing position there is a loss in saddle support, more lateral sway (Bertucci et al., 2005; Bouillod et al., 2018), and a forward shift in the cyclist's centre of gravity, when compared with a seated position (Caldwell, Li, McCole, \& Hagberg, 1998). This increases the degrees of freedom for segmental movements (Li \& Caldwell, 1998). Changing from a seated to a standing position alters muscle recruitment patterns, increasing muscle activation in both upper and lower body muscles (Chen, Wu, Chan, Shih, \& Shiang, 2016; Duc et al., 2008; Li \& Caldwell, 1998; Turpin, Costes, Moretto, \& Watier, 2017), and increasing transfer of power across the hip (Davidson et al., 2005). As a result of this, cyclists can produce greater power outputs in the standing position, when compared with a seated position during both prolonged cycling (Bouillod \& Grappe, 2018; Chen et al., 2016; Hansen \& Waldeland, 2008) and sprinting (Bertucci et al., 2005; Bertucci, Taiar, Toshev, \& Letellier, 2008; Merkes et al., 2020; Millet et al., 2002; Reiser et al., 2002; Rohsler et al., 2020). During uphill cycling, shifting from a seated to a standing position typically results in a lower cadence (Harnish et al., 2007), with a shift in the direction and an increase in the magnitude of the resultant pedal force (Caldwell, Hagberg, McCole, \& Li, 1999; Caldwell et al., 1998). Furthermore, the forward hip and knee positions induce changes in the hip (increase of $25 \%$ ), knee (increase of $\sim 44 \%$ ), and ankle joint moments (increase of $\sim 38 \%$ ) with a modified contribution of muscular and non-muscular forces (i.e. gravity) (Caldwell et al., 1999; Caldwell et al., 1998).

These changes in cycling biomechanics are associated with altered muscle recruitment as evidenced by alterations in the intensity and timing of electromyographic (EMG) activity of the hip and knee extensors (Caldwell et al., 1998; Li \& Caldwell, 1998; Turpin et al., 2017). For example, Turpin and colleagues (Turpin et al., 2017) reported that a standing position is favourable in terms of EMG at power outputs greater than $500 \mathrm{~W}$ due to positiondependent modulations of muscle activation levels. In addition to greater power output, cycling in a standing position has been shown to elicit greater heart rates, ventilatory responses (Millet et al., 2002), and mechanical cost (Bouillod \& Grappe, 2018; Bouillod et al., 2018; Hansen \& Waldeland, 2008). A greater mechanical cost (or decrease in efficiency) may be of concern during prolonged cycling in a standing position, such as observed during uphill cycling. However, it should be noted that when cycling at submaximal workloads a decrease in efficiency is not always critical to performance. Indeed, a short term increase in oxygen consumption when cycling submaximally uphill may not be problematic, when exercising below $\mathrm{CP}$. This is especially true if the change in position allows activation of different muscle groups (Arkesteijn et al., 2016), reducing localised neuromuscular fatigue. However, an increase in oxygen consumption resulting from a less efficient cycling position at the end of the leadup phase, when at or near VO2max (Menaspà, Quod, et al., 2015), may have significant implications for sprint performance. To the author's knowledge no study has yet compared movement efficiency during different cycling sprint positions following a fatiguing bout of exercise which replicates the lead-up phase of a final sprint in road cycling.

Standing while sprinting has a positive effect on power output when compared with a seated position (Bertucci et al., 2005; Bertucci et al., 2008; Merkes et al., 2020; Millet et al., 2002; Reiser et al., 2002; Rohsler et al., 2020). For example, Reiser and colleagues (Reiser et al., 2002) observed a 6 to $8 \%$ improvement in peak and mean power output while standing (19.4 and $11.0 \mathrm{~W} \cdot \mathrm{kg}-1$, respectively) during a 
$30 \mathrm{~s}$ Wingate, compared with sitting (17.9 and $10.4 \mathrm{~W} \cdot \mathrm{kg}-1$, respectively). By adopting a lower and more forward torso and head position to reduce aerodynamic drag (e.g. forward standing position) (Blocken, van Druenen, Toparlar, \& Andrianne, 2019; Crouch et al., 2019; Merkes, Menaspà, \& Abbiss, 2019a), the centre of gravity is presumably shifted forward and lower when compared with a more traditional standing position. Research has shown that during a 14 $\mathrm{s}$ sprint in a laboratory, recreational cyclists produce similar power outputs in the forward standing position compared with the standing position (Merkes et al., 2020). However, to date, no study has analysed the effect of a forward standing position on power output, muscle activation, force transfer, and performance in the field and might be an avenue for future research.

\section{Aerodynamics of Road Cycling Sprinters}

When cycling on level ground, air resistance is the main opposing force to the motion (Martin et al., 2006b). Indeed, air resistance represents up to approximately $95 \%$ of the total resistive forces experienced when cycling at $65 \mathrm{~km} \cdot \mathrm{h}-1$ (di Prampero, Cortili, Mognoni, \& Saibene, 1979). This resistance is dictated by air density, the airspeed of the bicycle, and the aerodynamic drag $(\mathrm{CdA})$. The $\mathrm{CdA}$ is the product of the drag coefficient $(\mathrm{Cd}$, dimensionless) and the combined projected frontal area of the cyclist and bicycle (Ap, in $\mathrm{m} 2$ ). The $\mathrm{Cd}$ is used to model all the complex factors of shape, position, and air flow conditions relating to the cyclist, and typically ranges from approximately 0.6 during a time trial to over 0.8 while riding on the hoods (Gibertini \& Grassi, 2008). In addition, Ap represents the proportion of an object (i.e. cyclist + bicycle) that can be seen by an observer placed exactly in front of that object (also known as the frontal area); that is the projected surface normal to the fluid displacement. It has previously (Martin et al., 1998) been suggested to combine $\mathrm{Cd}$ and Ap into a single variable, $\mathrm{CdA}$, as $\mathrm{Cd}$ is dominated by the turbulence associated with the cyclist's position, shape, size, and surface roughness; as Ap changes the flow over the cyclist will also change. In other words, decreasing Ap (due to changes in cycling position) does not directly result in a lower CdA. A correlation exists between measured $\mathrm{Cd}$ and Ap, in which Ap accounts for approximately $50 \%$ of the variation in drag between different cycling positions (Bassett, Kyle, Passfield, Broker, \& Burke, 1999).

External power required to overcome air resistance is a third polynomial of the velocity (Underwood, Schumacher, Burette-Pommay, \& Jermy, 2011), making it necessary to increase power output by $2 \%$ to increase cycling velocity by $1 \%$ only, when riding at 65 $\mathrm{km} \cdot \mathrm{h}-1$ (Martin et al., 2006b). Reducing CdA is therefore of high importance to road cycling performance, and even more in sprint performance since sprinting is the fastest activity in road cycling (with the exclusion of some descending). Given that the outcomes of road cycling sprints are often decided by very small margins, aerodynamics are extremely important to overall sprint performances. However, to date the majority of research into aerodynamics and cycling position have focused predominately on the time trial or prolonged cycling performance (Barry, Burton, Sheridan, Thompson, \& Brown, 2014; Barry, Burton, Sheridan, Thompson, \& Brown, 2015; Fintelman, Sterling, Hemida, \& Li, 2015; Garcia-Lopez et al., 2008; Underwood et al., 2011).

Changing from a seated to a standing position increases maximal power output but has a negative effect on $\mathrm{CdA}$, which increases by approximately 16.5\% (Blocken et al., 2019; Martin et al., 2007; Martin et al., 2006b; Merkes et al., 2019a). From data published on aerodynamics in cycling, it is known that lowering the torso (Barry et al., 2014; Fintelman et al., 2015; Garcia-Lopez et al., 2008; Underwood et al., 2011) and head (Barry et al., 2014; Barry et al., 2015), riding with the hands on the hoods compared with the drops (with the arms bend) (Barry et al., 2014), and bringing the arms inside the silhouette of the hips (Barry et al., 2014), all improved aerodynamics. Three recent studies using different measuring techniques (i.e. computational fluid dynamics and wind tunnel tests of static models of a cyclist (Blocken et al., 2019); wind tunnel tests (Crouch et al., 2019), and field tests (Merkes et al., 2019a)) have shown that lowering the 
torso and head (Blocken et al., 2019; Crouch et al., 2019; Merkes et al., 2019a), and moving the elbows inwards (Crouch et al., 2019) reduced CdA by approximately 25\% during road cycling sprints in both males (Blocken et al., 2019; Crouch et al., 2019; Merkes et al., 2019a) and females (Crouch et al., 2019). An improvement in aerodynamics, due to changing cycling position, should lead to a higher velocity for a given power output, and will therefore increase the likelihood of success in a road cycling sprint.

To date, performance within cycling literature is typically reported based upon power output data (i.e. $\mathrm{W}$ or $\mathrm{W} \cdot \mathrm{kg}-1$ ). However, it has been suggested that allometrically scaling power output (i.e. $\mathrm{W} \cdot \mathrm{kg}-0.32$ and $\mathrm{W} \cdot \mathrm{kg}-0.79$ ) may provide a better indicator of flat and uphill cycling performance, respectively (Faria et al., 2005b; Mujika \& Padilla, 2001; Padilla et al., 1999; Swain, 1994). This makes sense given the importance of body mass within cycling particularly when required to overcome gravity (i.e. uphill); however, it is unclear why it has not been used in more recent research. Additionally, as shown above, the main resistive force to overcome in a sprint is air resistance and not gravity. Although a number of studies have accounted for this by reporting power output relative to frontal area (W·Ap-1) (Menaspà, Quod, et al., 2013; Mujika \& Padilla, 2001; Padilla et al., 1999), decreasing Ap (due to changes in cycling position) does not directly result in a lower CdA, as noted above. Therefore, in future research it might be interesting to see if power output relative to $\mathrm{CdA}$ is a better indicator of road cycling success. This has been discussed in high performance cycling (Cycling-Power-Lab, 2014) but has not been reported in scientific literature to date.

\section{Measuring CdA in Cycling}

Aerodynamics are typically determined using either a wind tunnel or mathematical modelling. In a wind tunnel air flow is created with a fan in front of the cyclist-bicycle system. The assessment of CdA is determined based on ground reaction forces through force plate measurements (Debraux, Grappe, Manolova, \& Bertucci, 2011). Cyclists are placed on the bicycle on either a stationary force plate (passive) or on an ergometer on a force plate (active). The wind tunnel is the most valid and reliable technique to measure aerodynamics, and it can be used to assess different cycling postures, handlebars, frames, clothing, helmets, and wheels at different yaw angles (Barry et al., 2015; Chabroux, Barelle, \& Favier, 2012; Debraux et al., 2011; Garcia-Lopez, Ogueta-Alday, Larrazabal, \& Rodriguez-Marroyo, 2014; Garcia-Lopez et al., 2008; Oggiano, Troynikov, Konopov, Subic, \& Alam, 2009; Underwood, Jermy, Eloi, \& Cornillon, 2015; Underwood et al., 2011). Despite the high validity, reliability, and sensitivity, wind tunnel testing is relatively expensive and facilities are somewhat scarce. Practical fieldbased methods to assess $\mathrm{CdA}$ have therefore been established (Martin et al., 2006b; Martin et al., 1998).

Martin and colleagues developed (Martin et al., 1998) and updated (Martin et al., 2006b) a mathematical model which accounts for $97 \%$ of the variability in steady-state cycling power output when all the model parameters are known $(\mathrm{CdA}$, rolling resistance, drive train resistance, and changes in kinetic and potential energy). When power output is known (using a power meter) this model can be used for CdA calculations. These two mathematical models were shown to be valid methods for calculating $\mathrm{CdA}$ on the road (Martin et al., 2006b) and in the velodrome (Garcia-Lopez et al., 2014) when compared with a wind tunnel. The updated model uses Equation (2.1):

P_a $\cdot E-\Delta \mathrm{PE} / \Delta \mathrm{t}-\Delta \mathrm{KE} / \Delta \mathrm{t}=\mathrm{CdA} \cdot\left(1 / 2 \mathrm{Q} \llbracket \mathrm{V}_{-} \mathrm{a} \rrbracket \wedge 2\right.$ V_g $)+\mu \cdot\left(V_{-} g\right.$ F_N $)$

(Equation 2.1)

in which $\mathrm{P}_{-} \mathrm{a}$ is the average power output in Watts; $\mathrm{E}$ is the efficiency of the drive system (assumed to be $97.7 \%$ (Martin et al., 1998)); PE is the potential energy; $\mathrm{KE}$ is the kinetic energy; $\mathrm{CdA}$ is the aerodynamic drag; $\mathrm{Q}$ is the air density; V_g is the ground velocity of the participants in $\mathrm{m} \cdot \mathrm{s}-1 ; \mu$ is a global coefficient of friction (i.e. 0.004 or 0.006 for smooth and rough road, respectively (Martin, Gardner, Barras, \& Martin, 2006a)); and $\mathrm{F}_{-} \mathrm{N}$ is the normal force exerted by the bicycle tyres on the rolling surface (essentially total weight of 
the bicycle and participant). Using a mathematical model is cheaper and practically more available than the wind tunnel; however, multiple efforts of approximately 200 metres at different velocities are needed to calculate a single $\mathrm{CdA}$ value and therefore it is more time consuming.

The ideal solution would be to accurately measure $\mathrm{CdA}$ during regular races and training sessions. There are several companies who have developed or are developing devices to measure $\mathrm{CdA}$ in the field (e.g. Alphamantis Track Aero System (Bouillod, Pinot, Froncioni, \& Grappe, 2015), the Notio Konect Sensor array (Valenzuela et al., 2020), and the Velocomp PowerPod power meter). However, the Alphamantis Track Aero System is currently only usable in a velodrome, while the Notio Konect has not been validated for road sprints and the Velocomp PowerPod cannot be used for measuring aerodynamics during short efforts like sprinting (Merkes, 2020). The latter two devices measure opposing forces caused by changes in elevation, wind, acceleration, and friction (Merkes, Menaspà, \& Abbiss, 2019b; Valenzuela et al., 2020). Based upon these opposing forces $\mathrm{CdA}$ is calculated using algorithms. Real time calculation of $\mathrm{CdA}$ is an incredibly exciting area for cycling research; however, further work is required to determine the accuracy, reliability, and practicality of these devices.

\section{Bicycle Setup for Road Cycling Sprinting}

The interaction between the cyclist and bicycle is affected by numerous factors such as bicycle geometry and setup, crank length, and handlebar size. Establishing the best bicycle setup for a sprint is important but might differ to that of the rest of a race given that modifying bicycle setup can alter mechanical and energy cost (Peveler, 2008), CdA (Oggiano, Sætran, Leirdal, \& Ettema, 2008), and lower extremity kinematics (Rankin \& Neptune, 2010). Additionally, something like optimal gear ratios for a cyclist aiming to contest for a sprint during a hilly road race is problematic given the need to have appropriate gearing for steep climbs but also for a very fast sprint finish. A number of aspects related to bicycle geometry can be altered, of which saddle height and set back (distance of the tip of the saddle behind the bottom bracket) have been most frequently examined in research, given their impact on positioning and hence kinematics and kinetics of performance (Bini, 2011; Menard, Domalain, Decatoire, \& Lacouture, 2016).

Saddle height has an impact on both prolonged cycling and seated sprinting (Bini, 2011; Peveler \& Green, 2011). However, most road cycling sprints are performed in a standing position and therefore not affected by saddle height. Therefore, saddle height should be chosen to optimise prolonged cycling for multiple hours including a highintensity lead-up phase. Peak power output during a $30 \mathrm{~s}$ seated sprint was greater when saddle height was set to result in a knee angle of $25^{\circ}$ compared with a saddle height at $109 \%$ of inseam (Figure 3) (Peveler \& Green, 2011). Additionally, both these saddle heights with a knee angle of $25^{\circ}(\sim 3 \%)$ and at $109 \%$ of inseam $(\sim 1 \%)$ showed greater mean power outputs during the $30 \mathrm{~s}$ seated sprint when compared with a saddle height with a knee angle of $35^{\circ}$. Use of a saddle height with a $25^{\circ}$ knee angle was found to be more economical in relation to a saddle height with a $35^{\circ}$ knee angle and $109 \%$ of inseam (Bini, 2011; Peveler \& Green, 2011). This is in line with the literature recommending a saddle height with a knee angle of 25 to $30^{\circ}$ to minimise oxygen uptake (Bini, 2011).

The length of the crank arm has implications on joint range of motion and therefore affects the length-tension relationship of the working muscle. Furthermore, crank arm length affects the pedal speed at given cadences (Martin \& Spirduso, 2001) and therefore can potentially have an effect on muscle-shortening velocities, which have been shown to have optimal ranges (Hautier, Linossier, Belli, Lacour, \& Arsac, 1996). The literature contains some inconsistent results on the effect of crank arm length on power output during maximal efforts (Barratt et al., 2011; Inbar, Dotan, Trousil, \& Dvir, 1983; Macdermid \& Edwards, 2010; Martin, Malina, \& Spirduso, 2002; Martin \& Spirduso, 2001; Tomas, Ross, \& Martin, 2010; Too \& Landwer, 2000). Some studies indicate that cyclists can produce

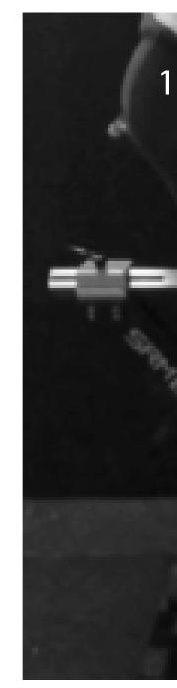

Figure 3 measured $\mathrm{K}$ = knee femoral e 
higher power outputs with intermediate crank arm lengths (range 145-180 mm), when compared with extreme crank arm lengths $(<140$ and $>200 \mathrm{~mm}$ ) (Inbar et al., 1983; Martin \& Spirduso, 2001; Too \& Landwer, 2000). More recent findings seem to agree that crank arm length does not affect peak power output (Barratt et al., 2011; Macdermid \& Edwards, 2010; Martin et al., 2002; Tomas et al., 2010). The latter studies account for changes in cadence, which strongly affects peak power output (Abbiss, Peiffer, \& Laursen, 2009; Dorel et al., 2005; Rylands, Roberts, Hurst, \& Bentley, 2017). Most of the studies available investigated large changes in crank arm lengths (>15 mm); however, these kinds of extreme crank arms lengths are not available on the market and are unlikely to be practical in road sprint cycling, particularly in technical race finishes with multiple sharp corners prior to the final sprint. To date, there are no studies available testing smaller changes $(<5 \mathrm{~mm})$ in crank arm lengths, which would be practically more relevant. Furthermore, most cycling sprints take place in a standing position and the effect of crank arm length on seated versus standing sprint performance has yet to be investigated.

Some road and track cyclists use narrower handlebars to improve aerodynamics (Delaney, 2018; Hurcom, 2015). Narrower handlebars may improve aerodynamics, but they might also have a negative effect on bicycle handling, upper body contribution to the sprint, and the capacity for the upper body to contribute to lateral sway. Therefore, it is just as plausible that it may be detrimental to real race performances. Further research is needed to determine the impact of handlebar width on aerodynamics and performance. In conclusion, what constitutes an optimal bicycle setup for road cycling sprinting is currently unclear and requires further research.

\section{The Interaction Between Cyclists}

In most professional road cycling races, there are over 100 cyclists participating. Therefore, the interaction between cyclists is likely to be an important consideration in performance. The biggest advantage of riding with other cyclists over riding solo, is that cyclists can shelter behind one another (drafting).

\section{Drafting}

The possibility of a cyclist drafting behind other cyclists, and thereby reducing their own $\mathrm{CdA}$, is one of the defining aspects of most races (except individual time trials). A wind tunnel study using 121 models of cyclists has estimated that cycling in a peloton can reduce the CdA down to $5-10 \%$ of an isolated cyclist for approximately $40-47 \%$ of the cyclists (depending on the density of the peloton) (Blocken et al., 2018). A reduction in CdA also happens when cycling in a smaller group (e.g. breakaway). The second cyclist in line experiences a reduction of approximately $30-$ $50 \%$ in $\mathrm{CdA}$ when compared with their individual CdA. The next cyclist experiences a reduction of approximately $35-55 \%$ compared with baseline. The area behind the first cyclist in line shows a reduction in pressure. Also, the high-pressure in front of the cyclist trailing them reduces the pressure differential. Both these pressure differences further contribute to the total reduction in pressure drag. The drag of the lead cyclist declines by $5 \%$ when another cyclist drafts behind him. This reduction is caused by the high-pressure in front of the trailing cyclist increasing the pressure behind the lead cyclist, thereby reducing pressure drag on the lead cyclist (Barry et al., 2015; Blocken, Defraeye, Koninckx, Carmeliet, \& Hespel, 2013; Crouch et al., 2017; Defraeye et al., 2014).

Due to a reduction in aerodynamic drag, trailing cyclists do not have to produce as much power output as the leading cyclist. A reduction in CdA down to $5-10 \%$ of an isolated cyclist corresponds to a cycling velocity of approximately 3.2-4.5 times lower than the peloton velocity (Blocken et al., 2018). Furthermore, a reduction in mean power output of $29 \%$ was observed when cycling in second position, and a reduction of $36 \%$ when 
cycling in third position compared with the leading cyclist (Broker, Kyle, \& Burke, 1999). A different study (Heimans \& Dijkshoorn, 2015) showed an even larger reduction in mean power for position two (34\%) and three $(43 \%)$. Velocity reported in both studies was similar ( 60 km.h-1); however, Broker and colleagues (Broker et al., 1999) used an outdoor track with efforts of $2000 \mathrm{~m}$, while Heimans and colleagues (Heimans \& Dijkshoorn, 2015) used an indoor track with efforts of $3000 \mathrm{~m}$. On the outdoor track CdA and therefore power output could have been affected by wind velocity and direction (Martin et al., 2006b). Additionally, the longer distance might affect fatigue and the ability to hold the same position for the full length. It can be concluded that a sprinter can save energy by drafting behind single and/or multiple cyclists during the whole race including the lead-up phase and the sprint itself.

\section{Team Tactics}

Road cycling is an individual sport (with exception of the team time trials and the recently introduced Hammer Series); however, team tactics are of great importance for performance outcomes. With multiple teams trying to win the race with their designated sprinter, it is highly plausible that cyclists can get in each other's way and the sprinters might not be able to sprint. This plays a major role in race outcomes and therefore teams often attempt an organised lead-out train in the final kilometres of a road race. Menaspà and colleagues (Menaspà, Abbiss, et al., 2013) analysed the number of teammates remaining at 60,30 , and $15 \mathrm{~s}$ before the finish line and the position in the bunch of one sprinter during won and lost mass sprint finishes. In this case study, the cyclist had one or two teammates leading him out at $60 \mathrm{~s}$ from the finish ( last $\mathrm{km}$ ) during won races, while rarely any teammates were in front of the subject in lost sprints. The support of the teammates was maintained until the final $15 \mathrm{~s}$ when, on average, one teammate was still in front of the cyclist. This team organisation may be responsible for the cyclist's positioning and smooth progression through the bunch in the last minute of each stage. At $60 \mathrm{~s}$ from the finish in won stages, the cyclist was significantly closer to the front of the bunch compared with stages resulting in a loss (i.e. 5th-6th vs. 9th-10th position). This study showed that team tactics can be of significant importance to winning professional cycling races finishing with a bunch sprint. Although the above results seem confirmed by anecdotal evidence and practical experiences, more studies confirming this and describing team tactics in different categories and in female road cycling would be needed.

\section{Conclusion}

A road cycling sprint can be described as 'the acceleration which occurs toward the end of competitions in order to reach the finish line in front of other competitors' (Menaspà, Quod, et al., 2015). During the sprint, male and female cyclists can reach high velocities, up to $70 \mathrm{~km} \cdot \mathrm{h}-1$. Performance outcomes in these sprints are affected by several variables including the cyclist's physiological capabilities, the interaction between the cyclist and their bicycle, and the interaction between cyclists. Professional male and female road cyclists produce a power output of approximately 14.2 and $10.0 \mathrm{~W} \cdot \mathrm{kg}-1$ over an average sprint duration of approximately 14 and $22 \mathrm{~s}$, respectively. It is well known that during a road cycling sprint, cyclists can generate more power output in a standing position than in a seated position. However, the standing position has a negative effect on aerodynamics compared with the seated position. Since air resistance is the highest resistance to overcome during a sprint, changing the standing position itself (e.g. lowering the torso and / or head) might result in better aerodynamics and therefore performance. Cycling in a peloton can reduce the CdA down to $5-10 \%$ for nearly half of the cyclists in the peloton. This means that a sprinter could ride at a very low cost in terms of energy before getting to the sprint. However, being close to the front of the peloton during the last part of the race, together with several teammates, seems to favour successful performance.

\section{References}

1. Abbiss, C. R., Burnett, A., Nosaka, K., Green, J. 
P., Foster, J. K., \& Laursen, P. B. (2010). Effect of hot versus cold climates on power output, muscle activation, and perceived fatigue during a dynamic $100-\mathrm{km}$ cycling trial. J Sports Sci, 28(2), 117-125. doi:10.1080/02640410903406216

2. Abbiss, C. R., Menaspà, P., Villerius, V., \& Martin, D. T. (2013). Distribution of power output when establishing a breakaway in cycling. Int J Sports Physiol Perform, 8(4), 452455. doi:10.1123/ijspp.8.4.452

3. Abbiss, C. R., Peiffer, J. J., \& Laursen, P. B. (2009). Optimal cadence selection during cycling : review article. Int SportMed J, 10(1), 1-15. Retrieved from https://journals.co.za/content/ismj/10/1/EJC48 370

4. Abbiss, C. R., Straker, L., Quod, M. J., Martin, D. T., \& Laursen, P. B. (2010). Examining pacing profiles in elite female road cyclists using exposure variation analysis. Br J Sports Med, 44(6), 437-442. doi:10.1136/bjsm.2008.047787

5. Arkesteijn, M., Jobson, S., Hopker, J., \& Passfield, L. (2016). The effect of cycling intensity on cycling economy during seated and standing cycling. Int J Sports Physiol Perform, 11(7), 907-912. doi:10.1123/ijspp.2015-0441

6. Atkinson, G., Davison, R., Jeukendrup, A., \& Passfield, L. (2003). Science and cycling: current knowledge and future directions for research. J Sports Sci, 21(9), 767-787. doi:10.1080/0264041031000102097

7. Bangsbo, J., Krustrup, P., Gonzalez-Alonso, J., \& Saltin, B. (2001). ATP production and efficiency of human skeletal muscle during intense exercise: effect of previous exercise. Am J Physiol Endocrinol Metab, 280(6), E956964. doi:10.1152/ajpendo.2001.280.6.E956

8. Barratt, P. R., Korff, T., Elmer, S. J., \& Martin, J. C. (2011). Effect of crank length on jointspecific power during maximal cycling. Med Sci Sports Exerc, 43(9), 1689-1697. doi:10.1249/MSS.0b013e3182125e96

9. Barry, N., Burton, D., Sheridan, J., Thompson, M., \& Brown, N. A. T. (2014). Aerodynamic performance and riding posture in road cycling and triathlon. Proceedings of the Institution of Mechanical Engineers Part PJournal of Sports Engineering and Technology, 229(1), 28-38. doi:10.1177/1754337114549876

10. Barry, N., Burton, D., Sheridan, J., Thompson, M., \& Brown, N. A. T. (2015). Aerodynamic drag interactions between cyclists in a team pursuit. Sports Engineering, 18(2), 93-103. doi:10.1007/s12283-015-0172-8
11. Bassett, D. R., Jr., Kyle, C. R., Passfield, L., Broker, J. P., \& Burke, E. R. (1999). Comparing cycling world hour records, 1967-1996: modeling with empirical data. Med Sci Sports Exerc, 31(11), 1665-1676. doi:10.1097/00005768199911000-00025

12. Bertucci, W., Taiar, R., \& Grappe, F. (2005). Differences between sprint tests under laboratory and actual cycling conditions. J Sports Med Phys Fitness, 45(3), 277-283. Retrieved from https://www.ncbi.nlm.nih.gov/pubmed/16230 977

13. Bertucci, W., Taiar, R., Toshev, Y., \& Letellier, T. (2008). Comparison of biomechanical criteria in cycling maximal effort test. Int J of Sports Sci Eng., 02(1), 33-46.

14. Bini, R. (2011). Effects of saddle position on pedalling technique and methods to assess pedalling kinetics and kinematics of cyclists and triathletes. (Doctor of Philosophy). University of Technology, Auckland

15. Bini, R. R., Rossato, M., Diefenthaeler, F., Carpes, F. P., dos Reis, D. C., \& Moro, A. R. P. (2010). Pedaling cadence effects on joint mechanical work during cycling. Isokinetics and Exercise Science, 18(1), 7-13. doi:10.3233/Ies-2010-0361

16. Bini, R. R., Tamborindeguy, A. C., \& Mota, C. B. (2010). Effects of saddle height, pedaling cadence, and workload on joint kinetics and kinematics during cycling. J Sport Rehabil, 19(3), 301-314. doi:10.1123/jsr.19.3.301

17. Blocken, B., Defraeye, T., Koninckx, E., Carmeliet, J., \& Hespel, P. (2013). CFD simulations of the aerodynamic drag of two drafting cyclists. Computers \& Fluids, 71, 435445. doi:10.1016/j.compfluid.2012.11.012

18. Blocken, B., van Druenen, T., Toparlar, Y., \& Andrianne, T. (2019). CFD analysis of an exceptional cyclist sprint position. Sports Engineering, 22(1), 10. doi:10.1007/s12283-0190304-7

19. Blocken, B., van Druenen, T., Toparlar, Y., Malizia, F., Mannion, P., Andrianne, T., Marchal, T., Maas, G. J., \& Diepens, J. (2018). Aerodynamic drag in cycling pelotons: New insights by CFD simulation and wind tunnel testing. J Wind Eng Ind Aerod, 179, 319-337. doi:10.1016/j.jweia.2018.06.011

20. Bouillod, A., \& Grappe, F. (2018). Physiological and biomechanical responses between seated and standing positions during distancebased uphill time trials in elite cyclists. J Sports Sci, 36(10), 1173-1178. doi:10.1080/02640414.2017.1363902 
21. Bouillod, A., Pinot, J., Froncioni, A., \& Grappe, F. (2015). Validity of Track Aero System to assess aerodynamic drag in professional cyclists. Paper presented at the Science \& Cycling, Utrecht.

22. Bouillod, A., Pinot, J., Valade, A., Cassirame, J., Soto-Romero, G., \& Grappe, F. (2018). Influence of standing position on mechanical and energy costs in uphill cycling. J Biomech, 72, 99-105. doi:10.1016/j.jbiomech.2018.02.034

23. Broker, J. P., Kyle, C. R., \& Burke, E. R. (1999). Racing cyclist power requirements in the 4000$\mathrm{m}$ individual and team pursuits. Med Sci Sports Exerc, 31(11), 1677-1685. doi:10.1097/00005768-199911000-00026

24. Caldwell, G. E., Hagberg, J. M., McCole, S. D., \& Li, L. (1999). Lower extremity joint moments during uphill cycling. J Appl Biomech., 15(2), 166-181. doi:DOI 10.1123/jab.15.2.166

25. Caldwell, G. E., Li, L., McCole, S. D., \& Hagberg, J. M. (1998). Pedal and crank kinetics in uphill cycling. J Appl Biomech., 14(3), 245259. doi:10.1123/jab.14.3.245

26. Capelli, C., Schena, F., Zamparo, P., Monte, A. D., Faina, M., \& di Prampero, P. E. (1998). Energetics of best performances in track cycling. Med Sci Sports Exerc, 30(4), 614-624. doi:10.1097/00005768-199804000-00021

27. Chabroux, V., Barelle, C., \& Favier, D. (2012). Aerodynamics of cyclist posture, bicycle and helmet characteristics in time trial stage. J Appl Biomech., 28(3), 317-323. doi:10.1123/jab.28.3.317

28. Chen, C. H., Wu, Y. K., Chan, M. S., Shih, Y., \& Shiang, T. Y. (2016). The force output of handle and pedal in different bicycle-riding postures. Res Sports Med, 24(1), 54-66. doi:10.1080/15438627.2015.1126276

29. Craig, N. P., \& Norton, K. I. (2001). Characteristics of track cycling. Sports Med, 31(7), 457-468. doi:10.2165/00007256200131070-00001

30. Crouch, T., Menaspà, P., Barry, N., Brown, N., Thompson, M. C., \& Burton, D. (2019). A windtunnel case study: Increasing road cycling velocity by adopting an aerodynamically improved sprint position. Proceedings of the Institution of Mechanical Engineers Part PJournal of Sports Engineering and Technology, 1-9. doi:10.1177/1754337119866962

31. Crouch, T. N., Burton, D., LaBry, Z. A., \& Blair, K. B. (2017). Riding against the wind: a review of competition cycling aerodynamics. Sports Engineering, 20(2), 81-110. doi:10.1007/s12283017-0234-1

32. Cycling-Power-Lab. (2014). Finding an ideal event position with 'The Golden Ratio' (Watts/CdA). Retrieved from https://www.cyclingpowerlab.com/WattsOve rCdA.aspx

33. Davidson, C. J., Horscroft, R. D., McDaniel, J., Tomas, A., Hunter, E. L., Grisham, J. D., McNeil, J. M., Gidley, L. D., Carroll, C., \& Thompson, F. T. (2005). The biomechanics of standing and seating maximal cycling power. Paper presented at the Med Sci Sport Exer.

34. De Pauw, K., Roelands, B., Cheung, S. S., de Geus, B., Rietjens, G., \& Meeusen, R. (2013). Guidelines to classify subject groups in sportscience research. Int J Sports Physiol Perform, 8(2), 111-122. doi:10.1123/ijspp.8.2.111

35. Debraux, P., Grappe, F., Manolova, A. V., \& Bertucci, W. (2011). Aerodynamic drag in cycling: methods of assessment. Sports Biomech, 10(3), 197-218. doi:10.1080/14763141.2011.592209

36. Defraeye, T., Blocken, B., Koninckx, E., Hespel, P., Verboven, P., Nicolai, B., \& Carmeliet, J. (2014). Cyclist drag in team pursuit: influence of cyclist sequence, stature, and arm spacing. J Biomech Eng, 136(1), 011005. doi:10.1115/1.4025792

37. Del Coso, J., Hamouti, N., Aguado-Jimenez, R., \& Mora-Rodriguez, R. (2009). Respiratory compensation and blood $\mathrm{pH}$ regulation during variable intensity exercise in trained versus untrained subjects. Eur J Appl Physiol, 107(1), 83-93. doi:10.1007/s00421-009-1101-y

38. Del Vecchio, L., Stanton, R., Reaburn, P., Macgregor, C., Meerkin, J., Villegas, J., \& Korhonen, M. T. (2019). Effects of combined strength and sprint training on lean mass, strength, power, and sprint performance in masters road cyclists. J Strength Cond Res, 33(1), 66-79. doi:10.1519/JSC.0000000000001960

39. Delaney, B. (2018). The narrowest bars in the pro peloton. Retrieved from http://www.cyclingnews.com/features/thenarrowest-bars-in-the-pro-peloton/

40. di Prampero, P. E., Cortili, G., Mognoni, P., \& Saibene, F. (1979). Equation of motion of a cyclist. J Appl Physiol Respir Environ Exerc Physiol, 47(1), 201-206. doi:10.1152/jappl.1979.47.1.201

41. Dorel, S., Hautier, C. A., Rambaud, O., Rouffet, D., Van Praagh, E., Lacour, J. R., \& Bourdin, M. (2005). Torque and power-velocity relationships in cycling: relevance to track sprint performance in world-class cyclists. Int J Sports Med, 26(9), 739-746. doi:10.1055/s- 
2004-830493

42. Duc, S., Bertucci, W., Pernin, J. N., \& Grappe, F. (2008). Muscular activity during uphill cycling: effect of slope, posture, hand grip position and constrained bicycle lateral sways. J Electromyogr Kinesiol, 18(1), 116-127. doi:10.1016/j.jelekin.2006.09.007

43. Elmer, S. J., Barratt, P. R., Korff, T., \& Martin, J. C. (2011). Joint-specific power production during submaximal and maximal cycling. Med Sci Sports Exerc, 43(10), 1940-1947. doi:10.1249/MSS.0b013e31821b00c5

44. Etxebarria, N., Ingham, S. A., Ferguson, R. A., Bentley, D. J., \& Pyne, D. B. (2019). Sprinting after having sprinted: prior high-intensity stochastic cycling impairs the winning strike for gold. Frontiers in Physiology, 10(100), 100. doi:10.3389/fphys.2019.00100

45. Faria, E. W., Parker, D. L., \& Faria, I. E. (2005a). The science of cycling: factors affecting performance - part 2. Sports Med, 35(4), 313337. doi:10.2165/00007256-200535040-00003

46. Faria, E. W., Parker, D. L., \& Faria, I. E. (2005b). The science of cycling: physiology and training - part 1. Sports Med, 35(4), 285-312. doi:10.2165/00007256-200535040-00002

47. Fernandez-Garcia, B., Perez-Landaluce, J., Rodriguez-Alonso, M., \& Terrados, N. (2000). Intensity of exercise during road race procycling competition. Med Sci Sports Exerc, 32(5), 1002-1006. doi:10.1097/00005768200005000-00019

48. Fintelman, D. M., Sterling, M., Hemida, H., \& Li, F. X. (2014). Optimal cycling time trial position models: aerodynamics versus power output and metabolic energy. J Biomech, 47(8), 1894-1898. doi:10.1016/j.jbiomech.2014.02.029

49. Fintelman, D. M., Sterling, M., Hemida, H., \& Li, F. X. (2015). The effect of time trial cycling position on physiological and aerodynamic variables. J Sports Sci, 33(16), 1730-1737. doi:10.1080/02640414.2015.1009936

50. Fukuba, Y., Miura, A., Endo, M., Kan, A., Yanagawa, K., \& Whipp, B. J. (2003). The curvature constant parameter of the powerduration curve for varied-power exercise. Med Sci Sports Exerc, 35(8), 1413-1418. doi:10.1249/01.Mss.0000079047.84364.70

51. Fukuba, Y., \& Whipp, B. J. (1999). A metabolic limit on the ability to make up for lost time in endurance events. J Appl Physiol, 87(2), 853861. doi:10.1152/jappl.1999.87.2.853

52. Gaitanos, G. C., Williams, C., Boobis, L. H., \& Brooks, S. (1993). Human muscle metabolism during intermittent maximal exercise. J Appl
Physiol, $75(2)$,

712-719.

doi:10.1152/jappl.1993.75.2.712

53. Garcia-Lopez, J., Ogueta-Alday, A., Larrazabal, J., \& Rodriguez-Marroyo, J. A. (2014). The use of velodrome tests to evaluate aerodynamic drag in professional cyclists. Int J Sports Med, 35(5), 451-455. doi:10.1055/s0033-1355352

54. Garcia-Lopez, J., Rodriguez-Marroyo, J. A., Juneau, C. E., Peleteiro, J., Martinez, A. C., \& Villa, J. G. (2008). Reference values and improvement of aerodynamic drag in professional cyclists. J Sports Sci, 26(3), 277286. doi:10.1080/02640410701501697

55. Gardner, A. S., Martin, D. T., Jenkins, D. G., Dyer, I., Van Eiden, J., Barras, M., \& Martin, J. C. (2009). Velocity-specific fatigue: quantifying fatigue during variable velocity cycling. Med Sci Sports Exerc, 41(4), 904-911. doi:10.1249/MSS.0b013e318190c2cc

56. Gardner, A. S., Martin, J. C., Martin, D. T., Barras, M., \& Jenkins, D. G. (2007). Maximal torque- and power-pedaling rate relationships for elite sprint cyclists in laboratory and field tests. Eur J Appl Physiol, 101(3), 287-292. doi:10.1007/s00421-007-0498-4

57. Gardner, S. A., Martin, T. D., Barras, M., Jenkins, G. D., \& Hahn, G. A. (2005). Power output demands of elite track sprint cycling. Int J Perf Anal Spor, 5(3), 149-154. doi:10.1080/24748668.2005.11868345

58. Gastin, P. B. (2001). Energy system interaction and relative contribution during maximal exercise. Sports Med, 31(10), 725-741. doi:10.2165/00007256-200131100-00003

59. Gibertini, G., \& Grassi, D. (2008). Cycling Aerodynamics. In H. Nørstrud (Ed.), Sport Aerodynamics (pp. 23-47). Vienna: Springer Vienna.

60. Haakonssen, E. C., Martin, D. T., Martin, J. C., Burke, L. M., \& Jenkins, D. G. (2013). Muscle mass-cycling power relationships in female road cyclists. Paper presented at the ACSM, Indianapolis In.

61. Hansen, E. A., \& Waldeland, H. (2008). Seated versus standing position for maximization of performance during intense uphill cycling. J Sports Sci, 26(9), 977-984. doi:10.1080/02640410801910277

62. Harnish, C., King, D., \& Swensen, T. (2007). Effect of cycling position on oxygen uptake and preferred cadence in trained cyclists during hill climbing at various power outputs. Eur J Appl Physiol, 99(4), 387-391. 
doi:10.1007/s00421-006-0358-7

63. Hautier, C. A., Linossier, M. T., Belli, A., Lacour, J. R., \& Arsac, L. M. (1996). Optimal velocity for maximal power production in non-isokinetic cycling is related to muscle fibre type composition. Eur J Appl Physiol Occup Physiol, 74(1-2), 114-118. doi:10.1007/bf00376503

64. Heimans, L., \& Dijkshoorn, W. (2015). The effect of aerodynamic characteristics on the drafting effect in track cycling. Paper presented at the Science \& Cycling, Utrecht.

65. Hoshikawa, H., Takahashi, K., Ohashi, K., \& Tamaki, K. (2007). Contribution of the ankle, knee, and hip joints to mechanical energy in cycling. J Biomech, 40, S750. doi:10.1016/s00219290(07)70738-8

66. Hurcom, S. (2015). Would you benefit from narrower handlebars? Retrieved from http://www.cyclingweekly.com/news/latestnews/would-you-benefit-from-narrowerhandlebars-199446

67. Impellizzeri, F. M., Ebert, T., Sassi, A., Menaspà, P., Rampinini, E., \& Martin, D. T. (2008). Level ground and uphill cycling ability in elite female mountain bikers and road cyclists. Eur J Appl Physiol, 102(3), 335-341. doi:10.1007/s00421-007-0590-9

68. Inbar, O., Dotan, R., Trousil, T., \& Dvir, Z. (1983). The effect of bicycle crank-length variation upon power performance. Ergonomics, 26(12), 1139-1146. doi:10.1080/00140138308963449

69. Jones, N. L., McCartney, N., Graham, T., Spriet, L. L., Kowalchuk, J. M., Heigenhauser, G. J., \& Sutton, J. R. (1985). Muscle performance and metabolism in maximal isokinetic cycling at slow and fast speeds. J Appl Physiol, 59(1), 132-136. doi:10.1152/jappl.1985.59.1.132

70. Konings, M. J., Parkinson, J., Zijdewind, I., \& Hettinga, F. J. (2018). Racing an opponent: Alteration of pacing, performance, and muscle-force decline but not rating of perceived exertion. Int J Sports Physiol Perform, 13(3), 283-289. doi:10.1123/ijspp.2017-0220

71. Konings, M. J., Schoenmakers, P. P., Walker, A. J., \& Hettinga, F. J. (2016). The behavior of an opponent alters pacing decisions in $4-\mathrm{km}$ cycling time trials. Physiol Behav, 158, 1-5. doi:10.1016/j.physbeh.2016.02.023

72. Li, L., \& Caldwell, G. E. (1998). Muscle coordination in cycling: effect of surface incline and posture. J Appl Physiol, 85(3), 927934. doi:10.1152/jappl.1998.85.3.927
73. Lucia, A., Hoyos, J., \& Chicharro, J. L. (2001). Physiology of professional road cycling. Sports Med, 31(5), 325-337. doi:10.2165/00007256-200131050-00004

74. Lucia, A., Joyos, H., \& Chicharro, J. L. (2000). Physiological response to professional road cycling: climbers vs. time trialists. Int J Sports Med, 21(7), 505-512. doi:10.1055/s-2000-7420

75. Macdermid, P. W., \& Edwards, A. M. (2010). Influence of crank length on cycle ergometry performance of well-trained female crosscountry mountain bike athletes. Eur J Appl Physiol, 108(1), 177-182. doi:10.1007/s00421009-1197-0

76. Martin, J. C., \& Brown, N. A. (2009). Jointspecific power production and fatigue during maximal cycling. J Biomech, 42(4), 474-479. doi:10.1016/j.jbiomech.2008.11.015

77. Martin, J. C., Davidson, C. J., \& Pardyjak, E. R. (2007). Understanding sprint-cycling performance: the integration of muscle power, resistance, and modeling. Int J Sports Physiol Perform, 2(1), 5-21. doi:10.1123/ijspp.2.1.5

78. Martin, J. C., Gardner, A. S., Barras, M., \& Martin, D. T. (2006a). Aerodynamic drag area of cyclists determined with field-based measures. Sportscience, 10, 68-69. Retrieved from http://www.sportsci.org/2006/jcm.htm

79. Martin, J. C., Gardner, A. S., Barras, M., \& Martin, D. T. (2006b). Modeling sprint cycling using field-derived parameters and forward integration. Med Sci Sports Exerc, 38(3), 592597. doi:10.1249/01.mss.0000193560.34022.04

80. Martin, J. C., Malina, R. M., \& Spirduso, W. W. (2002). Effects of crank length on maximal cycling power and optimal pedaling rate of boys aged 8-11 years. Eur J Appl Physiol, 86(3), 215-217. doi:10.1007/s00421-001-0525-9

81. Martin, J. C., Milliken, D. L., Cobb, J. E., McFadden, K. L., \& Coggan, A. R. (1998). Validation of a mathematical model for road cycling power. J Appl Biomech., 14(3), 276-291. doi:10.1123/jab.14.3.276

82. Martin, J. C., \& Spirduso, W. W. (2001). Determinants of maximal cycling power: crank length, pedaling rate and pedal speed. Eur J Appl Physiol, 84(5), 413-418. doi:10.1007/s004210100400

83. McDaniel, J., Behjani, N. S., Elmer, S. J., Brown, N. A., \& Martin, J. C. (2014). Joint-specific power-pedaling rate relationships during maximal cycling. J Appl Biomech., 30(3), 423430. doi:10.1123/jab.2013-0246

84. McLean, B. D., \& Parker, A. W. (1989). An anthropometric analysis of elite Australian track cyclists. J Sports Sci, 7(3), 247-255. 


\section{doi:10.1080/02640418908729845}

85. McLester, J. R., Green, J. M., \& Chouinard, J. L. (2004). Effects of standing vs. seated posture on repeated Wingate performance. J Strength Cond Res, 18(4), 816-820. doi:10.1519/14073.1

86. Menard, M., Domalain, M., Decatoire, A., \& Lacouture, P. (2016). Influence of saddle setback on pedalling technique effectiveness in cycling. Sports Biomech, 15(4), 462-472. doi:10.1080/14763141.2016.1176244

87. Menaspà, P., Abbiss, C. R., \& Martin, D. T. (2013). Performance analysis of a world-class sprinter during cycling grand tours. Int $\mathrm{J}$ Sports Physiol Perform, 8(3), 336-340. doi:10.1123/ijspp.8.3.336

88. Menaspà, P., Martin, D. T., Flyger, N., Quod, M., Beltemacchi, M., \& Abbiss, C. R. (2013). Maximal mean power of track and road sprint cyclists during World Class races. Paper presented at the ECSS, Barcelona.

89. Menaspà, P., Martin, D. T., Victor, J., \& Abbiss, C. R. (2015). Maximal sprint power in road cyclists after variable and nonvariable highintensity exercise. J Strength Cond Res, 29(11), 3156-3161. doi:10.1519/JSC.0000000000000972

90. Menaspà, P., Quod, M., Martin, D. T., Peiffer, J. J., \& Abbiss, C. R. (2015). Physical demands of sprinting in professional road cycling. Int J Sports Med, 36(13), 1058-1062. doi:10.1055/s0035-1554697

91. Menaspà, P., Quod, M., Martin, D. T., Victor, J., \& Abbiss, C. R. (2013). Physiological demands of road sprinting in professional and U23 cycling. A pilot study. J Sci Cycling, 2(2). Retrieved from https://www.jscjournal.com/index.php/JSC/article/view/60

92. Menaspà, P., Rampinini, E., Bosio, A., Carlomagno, D., Riggio, M., \& Sassi, A. (2012). Physiological and anthropometric characteristics of junior cyclists of different specialties and performance levels. Scand J Med Sci Sports, 22(3), 392-398. doi:10.1111/j.1600-0838.2010.01168.x

93. Merkes, P. F. J. (2020). Improving sprint performance in road cycling: The forward standing sprint position. (Doctor of Philosophy). Retrieved from https://ro.ecu.edu.au/theses/2315/

94. Merkes, P. F. J., Menaspà, P., \& Abbiss, C. R. (2019a). Reducing aerodynamic drag by adopting a novel road-cycling sprint position. Int J Sports Physiol Perform, 14(6), 733-738. doi:10.1123/ijspp.2018-0560
95. Merkes, P. F. J., Menaspà, P., \& Abbiss, C. R. (2019b). Validity of the Velocomp PowerPod Compared With the Verve Cycling InfoCrank Power Meter. Int J Sports Physiol Perform, 14(10), 1382-1387. doi:10.1123/ijspp.2018-0790

96. Merkes, P. F. J., Menaspà, P., \& Abbiss, C. R. (2020). Power output, cadence, and torque are similar between the forward standing and traditional sprint cycling positions. Scand J Med Sci Sports, 30(1), 64-73. doi:10.1111/sms.13555

97. Metcalfe, A. J., Menaspà, P., Villerius, V., Quod, M., Peiffer, J. J., Govus, A. D., \& Abbiss, C. R. (2017). Within-season distribution of external training and racing workload in professional male road cyclists. Int J Sports Physiol Perform, 12(Suppl 2), S2142-S2146. doi:10.1123/ijspp.2016-0396

98. Millet, G. P., Tronche, C., Fuster, N., \& Candau, R. (2002). Level ground and uphill cycling efficiency in seated and standing positions. Med Sci Sports Exerc, 34(10), 16451652. doi:10.1097/00005768-200210000-00017

99. Mornieux, G., Guenette, J. A., Sheel, A. W., \& Sanderson, D. J. (2007). Influence of cadence, power output and hypoxia on the joint moment distribution during cycling. Eur J Appl Physiol, 102(1), 11-18. doi:10.1007/s00421-007-0555-z

100. Moura, B., Luis Moro, V., Rossato, M., de Lucas, R., \& Diefenthaeler, F. (2017). Effects of saddle height on performance and muscular activity during the Wingate test. J Phys Educ, 28(1), e2838. doi:10.4025/jphyseduc.v28i1.2838

101. Mujika, I., \& Padilla, S. (2001). Physiological and performance characteristics of male professional road cyclists. Sports Med, 31(7), 479-487. doi:10.2165/00007256-20013107000003

102. Mujika, I., Rønnestad, B. R., \& Martin, D. T. (2016). Effects of increased muscle strength and muscle mass on endurance-cycling performance. Int J Sports Physiol Perform, 11(3), 283-289. doi:10.1123/IJSPP.2015-0405

103. Munro, L. A., Stannard, S. R., Fink, P. W., \& Foskett, A. (2017). Potentiation of sprint cycling performance: the effects of a highinertia ergometer warm-up. J Sports Sci, 35(14),

1442-1450. doi:10.1080/02640414.2016.1215492

104. Nimmerichter, A., Eston, R. G., Bachl, N., \& Williams, C. (2011). Longitudinal monitoring of power output and heart rate profiles in elite cyclists. J Sports Sci, 29(8), 831-840. doi:10.1080/02640414.2011.561869

105. Novak, A. R., \& Dascombe, B. J. (2014). Physiological and performance characteristics 
of road, mountain bike and BMX cyclists. J Sci Cycling, 3(3). Retrieved from https://jscjournal.com/index.php/JSC/article/view/104/2 36

106. O'Bryan, S. J., Brown, N. A., Billaut, F., \& Rouffet, D. M. (2014). Changes in muscle coordination and power output during sprint cycling. Neurosci Lett, 576, 11-16. doi:10.1016/j.neulet.2014.05.023

107. Oggiano, L., Sætran, L., Leirdal, S., \& Ettema, G. (2008). Aerodynamic optimization and energy saving of cycling postures for international elite level cyclists. Paper presented at the ISEA, Biarritz.

108. Oggiano, L., Troynikov, O., Konopov, I., Subic, A., \& Alam, F. (2009). Aerodynamic behaviour of single sport jersey fabrics with different roughness and cover factors. Sports Engineering, 12(1), 1-12. doi:10.1007/s12283009-0029-0

109. Olds, T. (2001). Modelling human locomotion: applications to cycling. Sports Med, 31(7), 497509. doi:10.2165/00007256-200131070-00005

110. Padilla, S., Mujika, I., Cuesta, G., \& Goiriena, J. J. (1999). Level ground and uphill cycling ability in professional road cycling. Med Sci Sports Exerc, 31(6), 878-885. doi:10.1097/00005768-199906000-00017

111. Padulo, J., Laffaye, G., Bertucci, W., Chaouachi, A., \& Viggiano, D. (2014). Optimisation of starting conditions in track cycling. Sport Sci Health, 10(3), 189-198. doi:10.1007/s11332-014-0192-y

112. Palmer, G. S., Dennis, S. C., Noakes, T. D., \& Hawley, J. A. (1996). Assessment of the reproducibility of performance testing on an air-braked cycle ergometer. Int J Sports Med, 17(4), 293-298. doi:10.1055/s-2007-972849

113. Parolin, M. L., Chesley, A., Matsos, M. P., Spriet, L. L., Jones, N. L., \& Heigenhauser, G. J. (1999). Regulation of skeletal muscle glycogen phosphorylase and $\mathrm{PDH}$ during maximal intermittent exercise. Am J Physiol, 277(5), E890-900. doi:10.1152/ajpendo.1999.277.5.E890

114. Peiffer, J. J., Abbiss, C. R., Haakonssen, E. C., \& Menaspà, P. (2018a). Sprinting for the win: Distribution of power output in women's professional cycling. Int J Sports Physiol Perform, 13(9), 1237-1242. doi:10.1123/ijspp.2017-0757

115. Peiffer, J. J., Abbiss, C. R., Haakonssen, E. C., \& Menaspà, P. (2018b). Sprinting for the Win; Distribution of Power Output in Women's Professional Cycling. Int J Sports Physiol Perform, 1-18. doi:10.1123/ijspp.2017-0757

116. Peveler, W. W. (2008). Effects of saddle height on economy in cycling. J Strength Cond Res, 22(4), 1355-1359. doi:10.1519/JSC.0b013e318173dac6

117. Peveler, W. W., \& Green, J. M. (2011). Effects of saddle height on economy and anaerobic power in well-trained cyclists. J Strength Cond Res, 25(3), 629-633. doi:10.1519/JSC.0b013e3181d09e60

118. Pinot, J., \& Grappe, F. (2011). The record power profile to assess performance in elite cyclists. Int J Sports Med, 32(11), 839-844. doi:10.1055/s0031-1279773

119. Pinot, J., \& Grappe, F. (2015). A six-year monitoring case study of a top-10 cycling Grand Tour finisher. J Sports Sci, 33(9), 907914. doi:10.1080/02640414.2014.969296

120. Poole, D. C., Ward, S. A., Gardner, G. W., \& Whipp, B. J. (1988). Metabolic and respiratory profile of the upper limit for prolonged exercise in man. Ergonomics, 31(9), 1265-1279. doi:10.1080/00140138808966766

121. Pro-Cycling-Stats. Most days of racing. Retrieved from http://www.procyclingstats.com/

122. Rankin, J. W., \& Neptune, R. R. (2010). The influence of seat configuration on maximal average crank power during pedaling: a simulation study. J Appl Biomech., 26(4), 493500. doi:10.1123/jab.26.4.493

123. Rauen, W. B., Angeloudis, A., \& Falconer, R. A. (2012). Appraisal of chlorine contact tank modelling practices. Water Res, 46(18), 58345847. doi:10.1016/j.watres.2012.08.013

124. Reiser, R. F., 2nd, Maines, J. M., Eisenmann, J. C., \& Wilkinson, J. G. (2002). Standing and seated Wingate protocols in human cycling. A comparison of standard parameters. Eur J Appl Physiol, 88(1-2), 152-157. doi:10.1007/s00421-002-0694-1

125. Rohsler, R., Campos, F. d. S., Varoni, P. R., Baumann, L., Demarchi, M., Teixeira, A. S., Lucas, R. D. d., Nunes, R. F. H., \& Flores, L. J. F. (2020). Performance comparison in the Wingate test between standing and seated positions in competitive cyclists. Motriz: Revista de Educação Física, 26. Retrieved from http://www.scielo.br/scielo.php?script=sci_art text\&pid=S1980-65742020000200302\&nrm=iso

126. Rønnestad, B. R., \& Mujika, I. (2014). Optimizing strength training for running and cycling endurance performance: A review. Scand J Med Sci Sports, 24(4), 603-612. doi:10.1111/sms.12104

127. Rylands, L. P., Roberts, S. J., Hurst, H. T., \& Bentley, I. (2017). Effect of cadence selection on peak power and time of power production in 
elite BMX riders: A laboratory based study. J Sports Sci, 35(14), 1372-1376. doi:10.1080/02640414.2016.1215491

128. Sallet, P., Mathieu, R., Fenech, G., \& Baverel, G. (2006). Physiological differences of elite and professional road cyclists related to competition level and rider specialization. J Sports Med Phys Fitness, 46(3), 361-365. Retrieved from https://www.ncbi.nlm.nih.gov/pubmed/16998 438

129. Sanderson, D. J., Mornieux, G., Guenette, J. A., \& Sheel, A. W. (2008). Influence of cadence, power output and hypoxia on the joint powers and muscle excitation during cycling. Paper presented at the NACOB, Ann Arbor, MI.

130. Santalla, A., Earnest, C. P., Marroyo, J. A., \& Lucia, A. (2012). The Tour de France: an updated physiological review. Int J Sports Physiol Perform, 7(3), 200-209. doi:10.1123/ijspp.7.3.200

131. Schabort, E. J., Hawley, J. A., Hopkins, W. G., Mujika, I., \& Noakes, T. D. (1998). A new reliable laboratory test of endurance performance for road cyclists. Med Sci Sports Exerc, 30(12), 1744-1750. doi:10.1097/00005768199812000-00014

132. Schumacher, Y. O., Mueller, P., \& Keul, J. (2001). Development of peak performance in track cycling. J Sports Med Phys Fitness, 41(2), 139-146. Retrieved from https://www.ncbi.nlm.nih.gov/pubmed/11447 $\underline{353}$

133. Sharma, A. P., Elliott, A. D., \& Bentley, D. J. (2015). Reliability and validity of a new variable-power performance test in road cyclists. Int J Sports Physiol Perform, 10(3), 278-284. doi:10.1123/ijspp.2014-0013

134. Skovereng, K., Ettema, G., \& van Beekvelt, M. (2017). The effect of cadence on shank muscle oxygen consumption and deoxygenation in relation to joint specific power and cycling kinematics. PLoS One, 12(1), e0169573. doi:10.1371/journal.pone.0169573

135. Skovereng, K., Ettema, G., \& van Beekvelt, M. C. (2016). Oxygenation, local muscle oxygen consumption and joint specific power in cycling: the effect of cadence at a constant external work rate. Eur J Appl Physiol, 116(6), 1207-1217. doi:10.1007/s00421-016-3379-x

136. Stellingwerff, T. (2012). Case study: Nutrition and training periodization in three elite marathon runners. Int J Sport Nutr Exerc Metab, 22(5), 392-400. doi:10.1123/ijsnem.22.5.392

137. Strutzenberger, G., Wunsch, T., Kroell, J.,
Dastl, J., \& Schwameder, H. (2014). Effect of chainring ovality on joint power during cycling at different workloads and cadences. Sports Biomech, 13(2), 97-108. doi:10.1080/14763141.2014.908946

138. Swain, D. P. (1994). The influence of body mass in endurance bicycling. Med Sci Sports Exerc, 26(1), 58-63. Retrieved from https://www.ncbi.nlm.nih.gov/pubmed/81337 40

139. Tofari, P. J., Cormack, S. J., Ebert, T. R., Gardner, A. S., \& Kemp, J. G. (2017). Comparison of ergometer- and track-based testing in junior track-sprint cyclists. Implications for talent identification and development. J Sports Sci, 35(19), 1947-1953. doi:10.1080/02640414.2016.1243795

140. Tomas, A., Ross, E. Z., \& Martin, J. C. (2010). Fatigue during maximal sprint cycling: unique role of cumulative contraction cycles. Med Sci Sports Exerc, 42(7), 1364-1369. doi:10.1249/MSS.0b013e3181cae2ce

141. Too, D., \& Landwer, G. E. (2000). The effect of pedal crank arm length on joint angle and power production in upright cycle ergometry. J Sports Sci, 18(3), 153-161. doi:10.1080/026404100365054

142. Turpin, N. A., Costes, A., Moretto, P., \& Watier, B. (2017). Can muscle coordination explain the advantage of using the standing position during intense cycling? J Sci Med Sport, 20(6), 611-616. doi:10.1016/j.jsams.2016.10.019

143. Underwood, L., Jermy, M., Eloi, P., \& Cornillon, G. (2015). Helmet position, ventilation holes and drag in cycling. Sports Engineering, 18(4), doi:10.1007/s12283-015-0181-7

144. Underwood, L., Schumacher, J., BurettePommay, J., \& Jermy, M. (2011). Aerodynamic drag and biomechanical power of a track cyclist as a function of shoulder and torso angles. Sports Engineering, 14(2-4), 147-154. doi:10.1007/s12283-011-0078-z

145. Valenzuela, P. L., Alcalde, Y., Gil-Cabrera, J., Talavera, E., Lucia, A., \& Barranco-Gil, D. (2020). Validity of a novel device for real-time analysis of cyclists' drag area. J Sci Med Sport, 23(4), 421-425. doi:10.1016/j.jsams.2019.10.023

146. Watsford, M., Ditroilo, M., Fernandez-Pena, E., D'Amen, G., \& Lucertini, F. (2010). Muscle stiffness and rate of torque development during sprint cycling. Med Sci Sports Exerc, 42(7), 1324-1332. doi:10.1249/MSS.0b013e3181ce509d 